\title{
The Influence of Poverty on Crime among the Abanyole of Emuhaya District, Western Kenya
}

\author{
Jared Aineah Ngutu \\ A thesis presented to the school of Postgraduate Studies and Research Kampala International University \\ Kampala, Uganda.
}

\begin{abstract}
The purpose of the study was to establish the significant relationship between poverty and crime in Emuhaya district of Western Province of Kenya. The objective of the study was to investigate the influence of poverty on crime amongst the residents of Emuhaya District in Western Province. The research design for the study was survey research design in which 5 point likert scale questionnaire on poverty and crime was used study to collect data from the respondents. The sample for the study consisted of 124 persons (Male 90 and Female 34). Data collected was analyzed using chi-square statistical method. Results indicated that there was significant relationship between poverty (financial standing, employment, family structure, social support, level of education and poverty) and tendency to commit crime among the people of Emuhaya district. The recommendation of the study is that improved systems of education and economic empowerment of the people should be enhanced by the government in order to reduce crime in the region among the 240,000 inhabitants of Emuhaya in Western Kenya
\end{abstract}

Keywords: Crime, level of education, employment, family structure, financial standing, Social support, Poverty

\subsection{Background To The Study}

\section{Introduction}

Emuhaya District has a population of over 240,000 people, $60 \%$ of this population live below the poverty line of less than 1 US dollar per day leading to poor standards of living. There is massive population explosion and pressure on the meagre resources like land, water, health, education, infrastructure, agriculture and some micro-finance enterprises in the region.

Due to the vicious cycle of poverty, there is gross violation of human rights as per the Geneva Convention that every person has the right to life, liberty and security. Other fundamental human rights violated in Emuhaya District included article 2 where men and women are to be treated equally which is not the case, instead they are subordinates and not allowed in decision making especially on assets. The area has been a high population growth of youths $(70 \%)$ who have neither trained, completed school or dropped out of school due to unemployment have resulted to violent crimes in the area such as murder, assault, rape, prostitution, theft, burglary, armed gangsters, banditry, trade in illicit rugs like bhang, changaa (local beer). Article 5 of the Declaration of Human Rights the states that no one shall be subjected to torture cruel inhumane or degrading treatment or punishment, economic or political liberty. The rights of the inhabitants of Emuhaya have been highly contested leading them to fall into traps of violent crimes in the region..

Poverty as a social phenomenon has affected the entire population in the region, poverty and inequality often results due to social instability, diseases, environmental degradation, struggle for natural resources and constraints on the basic needs in the society. In 1992 it was estimated that $42 \%$ of the approximately 525 million people in Sub-Saharan Africa lived below the poverty line of US \$ 370 per capita and the number was expected to increase by $50 \%$ in the year 2000 . It is noted that women, children, old age, disabled and the orphans are the most affected with poverty. The unstable micro-economic environment, poor development policies which yield to low economic growth not consistent with economic growth, poor infrastructure, dependency ratio in the area is also high. There is need for proper planning, decision making and economic empowerment of Emuhaya people to alleviate poverty in the region. The District budget allocation should be allocated, reviewed and strategic plans made to oversee the Constituency Development Fund (CDF) Local Government Transfer Fund (LATF), Women Development Fund, and Youths Fund to help improve the income of the people for better standards of living. "People must not be allowed to be come so poor that they offend or are hurtful to the society. It is so much that misery and plight of the poor but the discomfort and the costs of the community which is crucial to the view of the poverty. Poverty due to low income creates problems for those who are not poor". (Martya 1981)[1]

Crime as an act of sufficient challenges to the people of Emuhaya District has created fear for development and investment in the area which has no industry and processing services to bring income and employment to the area. Most of the businesses in the major towns are grocery, and casual labour especially in 
Luanda, Esibuye, Kilingili, Khumusalaba, Mwichio. Most of the occupation of Emuhaya is subsistence farming on small holdings mainly done by women to subsidize the family income. There are many crimes counted in the area such as juvenile delinquency as crimes counted be of children less than 18 years who make gangsters/ banditry, rape and murder people in the villages I.e. the Town Down gangsters of Luanda Town, the 42 brothers, and Musumbiji and others. Acts of crime, gambling, prostitution, vagrancy, homosexual are notorious to control in the District and thus referred to as victimless crimes. White collar crimes are committed by respectable persons through corruption. The purpose of this study is to investigate and establish the relationship between poverty and crime in Emuhaya District and recommend ways on reduction of crime.

The purpose the study was to establish the relationship between poverty and crime and make recommendations of helping the Abanyole people of Emuhaya and the government to alleviate poverty and crime in the area of study. The research is to generate ways of solving poverty through proper planning on investments, implementation of government projects solve unemployment, land tenure problems and enact a good policy legal framework to curb crime in the area.

Information from this study will be used by Governmental Departments i.e. Constituency Development Fund (CDF), Youth Fund, District Budgetary allocations, Education Offices, Provincial Administration and Non-Governmental Organizations to make right decisions to empower the economic status of the area to alleviate poverty and violent crimes as well as gross violation of human rights. The Ministry of Planning and National Development, Ministry of finance, The Office of the President and Provincial Administration to promote food security, health and sanitation services, investment and cur b violent crimes in the region. The study will be useful in investigating and establishing factors leading to poverty and how to curb them through the recommendations of the study in accordance to Malthusian's population Theory on Fundamental Human rights and conflicting theory on crime issues. The findings of this study will enable to put down factors leading to poverty and come up with strategic plans to help reduce it engage the entire population towards positive economic development of the area.

\subsection{Statement problem}

Poverty has a great influence on the crime rate in Emuhaya district of western Kenya. Poverty can be in state of absolute where there is lack of the basic resources needed to maintain minimum of the physical health, normally calculated in calories, while relative poverty has quantitative dimensions which refer to general standard f living in different societies due to cultural sensitivity and variations between and within societies over time. Poverty is due to massive inequality due to poor allocation of investment, education, planning and policy implementation, inadequate health facilities, human rights violations such as economic empowerment, right for protection, security, children's rights, and right to life.

Emuhaya area with a population of over 240,000 suffers from poverty and crime due to underdevelopment and expansive population which constraints the meagre available natural resources. There are no investments in the area apart from some small micro-finance investment Kenya Women Finance Trust (KWFT) which are created to help women start small business holds. The Constituency Development Fund $(\mathrm{CDF})$ is also geared towards enhancing small microfinance projects in education, infrastructure, youths, markets, farming in the area to alleviate poverty. There are conflicts over the scarce resources like land ownership, safe drinking water, streams, food, education, health which results into conflicts and criminal activities and offences due to poverty. Crime and violent conflicts is growing due to disparities in wealth, increasing unemployment among the youths, population press he on land and resources leading to environmental degradation which provokes social discontent, polarization leading to social strife in the region.

According to vigorous approach theory societal conditions of deep spread and deep poverty is essentially deprivation suffered by a large segment of some important essentials for sustenance such as sufficient income to provide housing, clothing, food and education, health facilities adequate opportunities for production employment which leads to societal stress. Stress leads to increasing the anger and frustration of the poor suffering who are then exploited by violence promoting war bent demagoguery. Indeed scarcities of the basic needs amongst the population causes social segmentation, group formation and strengthen groups identity which creates violent collective action which takes forms from rime war, terrorism, riots, civil insurgencies, political repressions to its ultimate forms.

Most of the inhabitants of Emuhaya live on subsistence farming on small holdings of less than Mi an acre and with poor farming methods, lack of farm inputs and technical agricultural know-how have lessen the yield to sustain the family needs. The are no income generating investments as factories, plantations (cash crops) to employ the youths and e working population in the areas leading to severe unemployment and crime in the region. In 1991 the United Nations crime prevention journals stipulated that crime has accelerated far beyond the current reach of international community. Crime is particularly serious impediment to harmonious development. It dissipates or misdirects the gains of economic growth and impairs the quality of life; crime threatens safety well being a d personal integrity of us all. (United Nations: 1991) Some other criminal offences 
conducted in the region is chang'aa brewing (local illicit brew)., substance abuse like bhang, cocaine, processor and trafficking of drugs in towns like Luanda, Kima, Ekwanda, Esibuye, Kilingili, Khumusalaba, and Esirulo has granted more crime impediment to investment in the region leading to absolute poverty. The study seeks to address the influence of poverty on crime, the consequences to the population in Emuhaya District and hence recommends ways to curb the menace.

\subsection{The purpose of the study}

The purpose the study was to establish the relationship between poverty and crime and make recommendations of helping the Abanyole people of Emuhaya and the government to alleviate poverty and crime in the area of study. The research is to generate ways of solving poverty through proper planning on investments, implementation of government projects solve unemployment, land tenure problems and enact a good policy legal framework to curb crime in the area.

\subsection{Research objectives}

The major objective of the study was to investigate the influence of poverty on crime amongst the residents of Emuhaya District in Western Province.

The specific objectives of the study will be:

1) To determine economic factors that lead to a vicious cycle of poverty in Emuhaya District

2) To investigate how poverty causes crime in the area of Emuhaya District.

3) To establish development plans to alleviate poverty in the region.

4) To assess types of criminal offences and when committed in the region and how they are solved.

\subsection{Research questions}

Study was guided by the following questions:-

1. What is the relationship between financial standing of the respondents and crime among the Abanyole in Emuhaya District in western Kenya?

2. What is the relationship between employment of the respondents and crime among the Abanyole in Emuhaya District in western Kenya?

3. What is the relationship between the family structure and crime of the respondents among the Abanyole of Emuhaya District in western Kenya?

4. What is relationship between the family support among the respondents and crime among Abanyole of Emuhaya District in western Kenya?

5. What is the relationship the level of education and crime of the respondents among the Abanyole of Emuhaya District in western Kenya?

6. What is the relationship between possession of property and crime of the respondents in Emuhaya region

\subsection{Null hypotheses}

1. There is no relationship between financial standing and crime among the Abanyole in Emuhaya District.

2. There is no relationship between employment and crime among the Abanyole in Emuhaya District.

3. There is no relationship between family structure and crime among the Abanyole of Emuhaya District.

4. There is no relationship between family support and crime among the Abanyole of Emuhaya District.

5. There is no relationship between the level of education and crime among the Abanyole of Emuhaya District.

6. There is no relationship between possession of property and crime among the Abanyole of Emuhaya District.

\subsection{The scope of the study}

The study covered Emuhaya District of Western Kenya which is one of the most poverty stricken areas resulting to violent crime, crimes against humanity and gross violation.

The study was limited to assess or establish the relationship between poverty and crime amongst 240,000 inhabitants of Emuhaya and its implication on the economic development within the region.

The study bases its guidelines on Malthusian theory of population to state the rationale on scarce resources leading to youth bulge and violence and conflict theory to explain crime and its effects in the study area. Since it was a wide area the findings were sampled from two major Divisions Emuhaya and Luanda. 


\subsection{Significance of the study}

Information from this study will be used by Governmental Departments i.e. Constituency Development Fund (CDF), Youth Fund, District Budgetary allocations, Education Offices, Provincial Administration and Non-Governmental Organizations to make right decisions to empower the economic status of the area to alleviate poverty and violent crimes as well as gross violation of human rights. The Ministry of Planning and National Development, Ministry of finance, The Office of the President and Provincial Administration to promote food security, health and sanitation services, investment and cur b violent crimes in the region. The study will be useful in investigating and establishing factors leading to poverty and how to curb them through the recommendations of the study in accordance to Malthusian's population Theory on Fundamental Human rights and conflicting theory on crime issues. The findings of this study will enable to put down factors leading to poverty and come up with strategic plans to help reduce it engage the entire population towards positive economic development of the area.

\subsection{Operational definitions of key terms}

Poverty: The vicious cycle of poverty has been defined as the phenomenon where poor families become trapped in poverty for at least three generations. The families have either limited resources or no resources. The concept of the vicious cycle of poverty holds that low productivity leads to low income, low income leads to low savings and low savings leads to low investment and low investment to low productivity.

Crime- A crime is a violation of criminal statutory law and a specific punishment applied by some government authority generally accompanies the violation. Criminal activities and crime rates vary in different legal jurisdictions which accompany differences in rates of enforcement.

\section{Poverty defined and its effects on society and individuals.}

Poverty can either be defined in terms of absolute or relative depending on the situation and geographical areas where the study is carried out. Absolute poverty is the measurable quality referring to lack of the basic resourced needed to maintain a minimum of physical health normally calculated in calories or nutritional levels while relative poverty has a qualitative dimension which refers to the general standards of living in different societies due to cultural sensitivity and variations between and within societies over time. According to Kulkarni (2005) poverty levels may be defined in absolute terms or relative in relations to the incomes of other members of the society thus family income is expressed as half of the medium income for all similar families. These illustrate that income disparities is the one that shows the economic difference in the standards of living in order to explain poverty cycles in the world. Kulkarni further states that, the official measure of poverty in the United States is based on more direct estimate the income is needed to provide a minimum standard of living, it begins with an economy food plan devised by the department of agriculture. The plan is supposed to provide a balanced diet at the lowest possible cost given the prevailing market prices (Kulkarni 2005; 411).This means the government of United States has to set the low income level the dividing line between the poor and non poor at three times the cost of the economy food plan.

In 2003, the low income levels were US Dollars 1866 for families of 4 , about $30 \%$ of the medium income. The World Bank estimates One US dollar or 2 US dollar per person per day as a measure of global poverty estimated at \$2920 per year for family of 4 members which is just $16 \%$ of the United States government poverty threshold. Comparatively, Sub -African states like Kenya, Uganda, Sudan, Tanzania and others are wanted to be some of the poorest in the world where half of the people live less than 1 US Dollar per day. It is said in Ethiopia 4 out of 5 people fall below the poverty line. [3] The World Bank projections estimates that in the quarter century from 1990 to 2015 poverty measured at a threshold of 2 US dollar per day will decline by $62 \%$ of the world's population growth to $38 \%$ even taking population growth into account there will be $15 \%$ total poor people in 2015. The argument here does not put the true picture of the African countries whose economic growth is declining daily due to poor educational systems, unemployment, inadequate medical care, poor infrastructure, lack of technical skills and technological know-how in wealth creation and economic planning to avert poverty. The Sub-Saharan Africa has a bleak future in averting poverty from the continent. According to the World Bank millennium goals off 1990-2015 the percentage of Africa's population in poverty will fall from $76 \%$ to $70 \%$ due to competition on the available resources due to rapid population explosion. The population of the poor has been projected to rise by nearly $60 \%$ by 2015 . This is a great challenge to our national government to come up with strategic leadership and strategic planning on the resources to reap the economies to improve welfare and standard of living of the people in Africa and world. [3]

According to World Bank (1990) poverty is the inability to attain a minimum level of a standard of living which considers income and expenditure per capita to be the standard of measuring welfare. This definition is meant to determine the household who falls below or above the minimum standard of living and classify them as poor or non-poor respectively. Gewwe and Gaag (1990) define poverty as an interlocking condition of assertiveness, unemployment, low wages and income, proneness to disease, illiteracy, gender and 
economic vulnerability, social advantages and political powerlessness which reflect on the living conditions of Abanyole of Emuhaya District the study area. The economic conditions, life style and other socio economic needs are difficult to meet. Poverty may also be related to lack of property (Assets) attributed to poor housing, few or no assets, lack of sanitation, safe drinking water, inadequate health facilities, insecurity, in access to educational facilities and lack of technological information. This is a common phenomenon in African sates which narrows down to Emuhaya district of western Kenya where poverty is the order of the day. [3]

Poverty cycles creates inequalities which is defined as lack of achievement of any given welfare indicator in income or consumption or any value attributes of a population. Government with inequalities within the population has explosive violence in which the rich and the poor live side by side in urban centres and villages social disparities fuelling conflicts. Poverty and income deprivation is where the basic necessities of food, housing, clothing, educational, health services, dignity, squalor fatigue, fatalism are its hallmark and is accompanied by cultural or psychological aspects that are impossible to measure. These is accompanied by stress and grievances leading to collective action of violent nature, crime, demonstrations, theft, burglary, school drop outs, diseases, malnutrition generally depicted as low standards of living leading to conflicts between the rich and the poor. The gap between the rich and the poor in developing states breed stress and crime thus need proper government interventions to provide the human basic needs to all to avoid inequality.

There are conflicts over natural resources like land ownership, environmental change, eater scarcity, food shortages that are linked to social and economic development of particular areas in the world. The conflicts come due to disparities in wealth, increasing unemployment, job securities, population growth and environment; degradation that provoke social discontent and polarization leading to political strike in many African countries. Kenya is also facing the similar problem on the allocation of the resources and government budgetary allocations and expenditures to rural areas where $80 \%$ of the poor live, Emuhaya district in Western Kenya has similar disparity situation of misallocation of funds and poverty excavations of the massive population. According to rigorous theory, societal conditions of widespread and deep poverty is essentially depreciation suffered by a large segment of some important essentials for sustaining a sufficient income to provide housing, clothes, food, education, health services and adequate opportunities for productive employment which lad to societal stress increasing anger and frustrations of the poor in Emuhaya District, leading to violation of human rights on economic, political and social aspects of life. The scarcity of basic human needs contributes to heightened grievances, actor opportunities structures through social segregation (group formation and identify), damage relationship between the state and the society and create insecurity to the rich and the poor. In Emuhaya the Abanyole people have this problem of scarcities of basic needs which has made the poor counter parts. There is great division between these two groups, fear of burglary and murder is the order of the day. The situation remains to be addressed since the police and law enforcers are defeated to curb it.

Denator Douglas Roche states in his book a Political Agenda for Social Justice that the modern wars do not just happen, they spring from the terrible disparities in the possession of wealth and resources. This was complemented by United Nations former Secretary General Kofi Annan who stated that political violence occurs more frequently in poor countries due to failures of governance to redress horizontal inequalities. Indeed the income gap between the average person who lives in a poor developing country and the average person who lives in the rich in industrialized countries have been widening steadily over the past years. Ken a being in his category attributes the same to Emuhaya district where the poor make $80 \%$ of the population. The area has remained marginalized since independence in 1963, no investment like factories, proper agricultural technologies to improve farming, inadequate learning facilities, poor health care, low level education, low financial standing due to unemployment have weakened the social fabric of the are as many households live below the poverty line of less than one US Dollar per day.

Kenya government does not have a national poverty line. In 1994 welfare monitoring survey (WMS II) conducted by the Central Bureau of statistics (CBS) defined poverty line for rural and urban areas at Kenya shillings 978 per capita for rural per month which can be translated to Ksh 32 and Ksh 410 respectively. When looking at this statistics, this money has no purchasing value in the local market. One would need to work for 4 days to buy a day's meal leading to extreme poverty which characterize indigence and destitution (in ability to satisfy the minimum needs). A casing point is Emuhaya study area when the cost of living is 0 high and the income levels are too low. Most people have small plots o land of 1/4 acre with households of 6-8 children, parents are unemployed so all the resources are purchased from Luanda market and other market centres like Esibuye, Miwichio, Ekwanda. Kima, Kilingili, Emabungo, Ipali, Duka Moja, Khumsalaba where commodity prices are high due to price fixing by the sellers.[41]

Emuhaya study area has been characterized by food poverty which is defined as the consumption below normative minimum level, which takes into account nutritional standards that are necessary for healthy growth and maintenance of the human body. The Federation of agricultural Organization and World Health Organisation minimum recommended daily allowance of food energy is 2,250 calories per adult equivalent. The food poverty line for all the Kenyans has been set. Emuhaya, district is already disadvantaged as most people 
live by one meal per d or starve. The main stable food is ugali which is always taken with vegetables or what accompaniment the house hold head can afford. To take a balanced diet in a household of 4 members one needs at Kshs 500 per ay yet the majority of the population earn less than Kshs 50 per day. The entire population of 240,000 people or Emuhaya experience food poverty, income poverty and human poverty. United Nations Kenya Human Development Report (1999) report defines human poverty as lack of essential human capacities such as literate, adequate nourishment and good health. Income poverty is the lack of adequate income or expenditure to meet the minimum basic needs and is measured in terms of income and expenditure. [8]

The poverty incidences in district and urban centres in Kenya are high and reflect the majority are poor. It is estimated that more than $10 \%$ of the Nation's poor line in Machakos and Kakamega districts from which Emuhaya district was curved. The poverty incidence in Kakamega was 67\% in $1994 \%$ compared to Makueni and Siaya, Kitui and Bungoma. The report states that the poor are concentrated in districts land urban boarding Lake Victoria in the west stretching to the railway line mad transport commodores extending to Kilifi and Indian Ocean coast. The characteristics of this poor category of the population are small scale farmers, pastoralists, agricultural labourers, unskilled and semi skilled, casual labourers, female households, the physically handicapped, HIV/AIDS or orphans and patients, street children. All these categories if the poor make the major percentage of Emuhaya population. There is need to improve on the average conditions of the poor to alleviated hunger and poverty in Emuhaya and among the Abanyole in the study area. Poor infrastructure, lack of income earning opportunities, declining government services, insecurity and political unrest worsen the poverty and civic leaders are requested to improve on broken promise, corruption, nepotism and lawlessness. The poor feel they are excluded from decision making, economic, social and political process. There is inequality amongst the men and women on land ownership, wealth and income, in access to economic and social goods and services, remunerative jobs, participates in social and political process ii Emuhaya area. Women mainly take domestic tasks, hawking business by selling cereals, vegetables, and fish in markets to passengers in vehicles to earn a living in their households.

Nyong'o (1990) looks at poverty as a main pre-occupation of the independent African has been to achieve economic growth and development and countries to state that at independence most of the African countries were ill-equipped to pursue modern economic growth because their capital stock was small and relatively unsophisticated. Their labour force was largely unskilled and production methods were based on traditional technologies. The small size of African economies and their restricted markets were major handicaps to the increased population. "In spite of being rich both human and natural resources, a picture has been painted that African situation was hopeless, devastated by wars, famine, diseases and debt crisis, observers tend to conclude that African had gone backwards and not made any visible progress since independence. [14]

The Kenyan Constituency Development Fund (KCDF) is an act of the Parliament Act (2003) of the Kenya Gazette Supplement No 107 (Act No 11) dated $9^{\text {th }}$ January 2004 helps to disburse the central government annually to improve on the well being of the people. In Emuhaya the CDF offices based in Luanda market has financial and strategic committees which funds and implements poverty alleviation projects. The fund is starting to provide good services to improve the welfare of the poor in the region. The major projects are education; infrastructures the roads, schools, health centres, water and sanitation, micro finance projects, agriculture, youth and women empowerment, rural electrification are given emphasis to sustain development in the study area of Emuhaya. The Constituency Development Fund (CDF) in 2010 was allocation to various statuses of the Abanyole people of Emuhaya. Education sector received Ksh 27 million to improve the education standards and improve vocational training like Esalwa, Emukunzi, Maseno polytechnic and Ebusiralo Polytechnic were funded for establishment on the youth training programmes in technical skills and capacity building courses. [46] Emuhaya areas has a large population that need good medical and healthcare facilities to improve the health conditions of the $\mathrm{p}$ le faced with low income and food poverty. The Constituency Development Fund (CDF) has tried to initiate District Hospital at Emuhaya at a cost of 20 million Kenya shillings besides Emusire health centres, Ekwanda, Ipali, Ebusyubi, Mumboha, Ebukanga, Ematsuli, Ebusiratsi, Esaba, Musitinuyi and Ekamanji health centres and dispensaries have been established to improve the lively-hood of the people. Most of these hospitals lack enough personnel since the government cannot employ due economic constraint. There is a fight against jiggers evidenced by 8 victims treated at Ebukanga Primary School in Central Bunyore location at a cost of Ksh 80, 000 through Ahadi Trust Kenya an NGO involved in ginger eradication. This is an illustration of the poor who live in hostile economic 4 conditions in the study area. The majority who languish in poverty have poor housing, illiterate, malnourished (food deficient), hopeless and powerless. The survival of most people in Emuhaya District is through dependency on the few household heads and relatives. [46]

The Universal Human Rights Development of December 1948 article. 25 states that everyone has the right to life and a good standard of living adequate for health and well being of himself and of his family, including food, housing and medical care, necessary social services and the right to security in the event of employment, sickness, disability, widowhood, old age or other lack of live-hood in substances beyond his control. This enforcement has not been implemented in Kenya and her districts leading to inequalities in 
income, social economic aspects of life as far as the alleviation of poverty is concerned for the improvement of living standards Kenyans in Emuhaya region. The Kenyan New constitution of 6th may 2010 National Hunan Rights and Equality commission chapter 4 on the Bill of Rights. Chapter 5 Article 59 section 2(d) states the Kenyan National Commission o the Human Rights (KNHR) will receive and investigate any report on the observance of the human rights in all spheres of life in the Republic of Kenya including observance by the National Security organs and in section 2(e) states that the commission shall receive and investigate complaints about alleged abuses of human rights and takes steps to secure appropriate redress where human rights have been violated. In Emuhaya the division between all the classes of people the rich and the poor, the educated and Non- educated, Youths and the age, women and men fail to meet the standards of a positive response towards issues of poverty. There a is serious disparities in all aspects of life thus none is remittance of Human Rights information on the Marginalize in Emuhaya to the Kenyan Government and even the NGOs who could fund projects to improve the standards of the people. The Kenyan institution on economic and social rights stipulates that everyone has me light to the highest attainable standards of health, which includes the right to health care services, including reproductive health care and should access adequate food of acceptable quality, clean and safe water in adequate quantities, access social security and have education. [34]

The Uganda Implementation of Fiscal Decentralization Strategy (UIFDS) in Bushenyi and Tororo Districts Report No 7 Debt Network 2005 denotes the plans and programmes that reflect poverty eradication, mobilize and channel local resources into those programmes and activities that impact on poverty. The programmes lay the stress on Poverty Eradication Action Plans (PEAP) to influence the budget allocation across all the sectors of employment and even National budgets Sector allocation among Sector Development Plans (SDP) influence allocations within and among sectors in the National budgets while the Local Government Development Plans (LDGP) then the Sector Development Committees (SDC) does the implementation on behalf of the Uganda government. Uganda has Poverty Action Plan Fund (PAPF) a strategy to rationalize PEAP change the pattern of public expenditure to meet the needs of the poor which was intended to strengthen the ability of the district to deliver the services attuned to the needs of the people. The Emuhaya District should borrow a leaf from the Uganda system of attacking poverty and use Community Development Fund (CDF) to make strategic plans for the districts and forward to the central government in Nairobi for undoing the projects as prioritized in the budgetary allocations. State political leadership working together without antagonism filter among e technical people, Bushenyi provides itself team work, brain storming, being transparent and accountable to the people and similarly work is done in a timely and proper way according to the criteria set to achieve the value for money (Uganda Debt Network Vol. 7, 2005,). It calls for the political wing and stakeholders to embrace co consensus team spirit transparency and accountability to reduce poverty in Emuhaya among the Abanyole in Emuhaya district of Western Kenya. [6]

The Kenyan government should focus on primary economic objectives to promote rapid, broad-based and sustainable private sect leading to economic growth as a pre- requisite for poverty reduction. Uganda government (2004) emphasizes on prudent financial management in the legislations accord that provides the legal framework and the prescriptions for control on administrative accounting for the. Public funds which entail micro economic and fiscal policy, budgeting utilization of resources, accounting and reporting, auditing by the Auditor General, General reporting to parliament and feed back from s parliament. (Uganda Debt Network volume 6,2004$)[5]$

According to the research the poor female adult are more prominent in rural areas of the world while the youthful female are in urban centres. The aged women take care of the households and are tied to domestic tasks like peasant farming, livestock rearing, poultry and small business holdings to generate income for the families. Most of them have low levels of education and cannot meet urban standards. The- female youth $\hat{A}$. mo; engaged in casual work and even prostitution to earn ally wages for sustainable living leading them to vulnerability of violence d diseases like STIs and HIV/AIDS. In Uganda the unfair gender relations make women to face difficulties to access property such as land, investments and even education a casing point for Emuhaya district where women are restricted to access some property. The persistence of poverty a mid macro economic studies reflect lack of coherent emphasis on the link between micro and macro economy as targeted. There are the entrepreneurs at all levels, the farmers both peasants and commercial industries use Juakali skills in various small scale industries. But without the attendants supporting public infrastructures in terms of good road network, functioning health systems and reliable information channels the macro economy studies becomes completely irrelevant for the micro economy. The budget seems to be silent on some of these important aspects as they partly explain the persistence of biting poverty. (Uganda Budget 2003/2004 pages 11-12). [5]

The prospects for Kenya meeting its poverty reduction targets by the Millennium Development Goals (MUGS) remain bleak; in 2006 was $46 \%$ of the population was unable to meet essential food and Non food requirements. Improvement during the recent years has been too slow $t$ reach the millennium development goals by the year 2015. According University of East London research shows that the inequality and extra poverty bad increased by $20 \%$ in 2006 . When this situation is attributed to Emuhaya it even poses more danger to the 
economic development. Analysis carried out in 2005 concluded that Kenya will need US \$1 billion to meet the (MDGS) by 20.15. The donor funding has been US $\$ 1$ million due to suspicion of government standards for rear corruptions and instability. Kenya being an agricultural country, with only $18 \%$ of its territory suitable for farming has no food sufficiency to feed its citizen. The country is also vulnerable to successive years of drought up to 2006 which compelled the World Food Program me (WFP) to offer food, for over 3 million people (http//.u.lconeworld.net/guides/Kenya/development). There were severe floods in Kenya between 2004-2007 that affected over 700,000 in areas of Kano in Kisumu district, Budalangi, Busia, Narok, Coast and Central Province leading to poor infrastructures, housing, farm crops, leading to National food insecurity ending up with hunger and poverty among the entire population. [8]

The food security challenges were worsened by the marred 2007 Kenyan elections where the major agricultural regions in Western, Rift Valley, Nyanza and Coast province of Kenya were affected in there are conflicts with several destructions in both storage of food and farm inputs. Millions of people displaced from their farms leading to low production on farms to meet food security stretching the state to extra poverty situations. During that time a packet of maize meal was selling at Ksh 120 and 200. Few supplies which appeared at the market were exorbitantly charged as the demand was high. The poor wit in Emuhaya who entirely depend on market supply were unable to me their daily socio-economic needs for lack of income. UNDP Human Development Report (2007) states that man-made shocks act on vulnerability to poverty and more familiar extreme of weather. The post election turmoil in the early 2000 disrupted the March planting season with only $5 \%$ of the farmers not sufficiently prepared with signs of erratic rainfall in the arid regions and the rising food prices, stocking inflation, were warnings of potential food insecurity in Kenya by the end of 2008. (http:uk.Oneworld.net/guides/Kenya/development).

Ndeye Showed that in Burundi, the percentage of the population leaving under the poverty line went up from 35\% in 1992 to 7\% in 2005 and in DRC the poverty Reduction Strategy Paper (RRSP) estimated at 80\% of the population was living under a dollar per clay. This poverty remains high in Rwanda with $60 \%$ of the population still living below the poverty line. Indeed effects of conflicts and crime determine economic development of a nation stretching poverty burdens to the civilians. The Abanyole of Emuhaya fall in the same poverty trap due to instability of the government and poor planning policies at rural levels. [37]

According to Kenya National Survey Results (April 2009) on the evaluation of socioeconomic conditions and insecurity research revealed that Kenyans frequently looked to sources other that their own individual efforts to secure a livelihood. The fact that the social capital $(53.7 \%)$ borrowed from family and friends at $45 \%$, there is dependence on remittances from family working elsewhere paid wage or salary. Kenyans live in the want at the periphery of the cash economy; indeed the socioeconomic situations in the country is wanting, availability of consumer goods, job opportunities, poor standards of living, conflicts between different groups, corruption of public officials and tribalism have increased poverty among Kenyans. In 2009 thousands of tones of imported maize was alleged to be contaminated hence disposed an indication of a corrupt government. The relief foods brought to assist the poor is misused by the chiefs and other civil servants access to them. The orphans, disabled, old age hardly receive adequate assistance in Emuhaya district. [41]

The majority of the youths languish in poverty in Kenya because they are jobless, low level of education so they gang up to cause crime in homes stealing to earn a living. According to the Emuhaya Youth Affairs Depart and Constituency Development Fund Committee (CDFC) over 500 youth Groups have been registered on Micro-Finance projects to boost their standards of living, former Minister for Agriculture in Kenya Honourable William Ruto presided over a youth fundraising which realized Ksh. 1,360,000 in August 2009 and was loaned to76 Groups each given Ksh 10, 000 to start an income generating projects and also reduce unemployment problem in the study area. The Constituency Development Fund was also disbursed Ksh 2, 000, 000 to fund 40 youth groups with each getting Ksh 50,000 to keep the venture into small business but pay back the revolving loan. According o the youth affairs officer in the CDF offices, the youth have squandered the money and no income generating activity is taking place in most of the groups. This is a sign of irresponsibility possibly linked to inadequate education and technical skills in socioeconomic activities. [43]

The poverty has brought inequality among the poor and the rich in Emuhaya district especially the Abanyole people. There in need for a sound strategic planning on poverty reduction and implementation to improve the welfare of the people in accordance to the human rights. There has been an appeal for individual's economic, social and political rights by the United Nations Declaration Human Rights 1998 and the African charter on Human and people Rights of 1981.

\subsection{The effects of poverty on society and individuals}

According to the past and present research poverty impacts a lot on the economic development of a people and the nation as a whole. There are high risks of educational underachievement of children who from low income households. The problem begins at primary level to other levels of education. Children from poor families drop-out of school and practice juvenile delinquencies in the community. Teenage pregnancy is 
experienced on girls from the low income family. This is true in Emuhaya region because the majority of children dropout of school and those who complete primary education (Kenya Certificate of Primary Education - KCPE) hardly pursue High school and even few who attend high school do not perform poorly due to poor family background. The 2009 KCPE results for Emuhaya 11 students attained 400 marks and above, similarly the 2009 Kenya Certificate Secondary Education (KCSE) examinations performance were poorly done, only one student obtained A plain as compared to 10 students in 2008 (Emuhaya News magazine issue No 5 JanuaryMarch 2010). This is an indication that poverty is a key contributor to students impoverishment, hopeless and powerless thus deterring the educational standards in the region.[46]

Families and societies who submit low levels of investment in education and development of less fortunate children end up with less favourable results for the children. Very few of the citizens of Emuhaya reach University level due to poor academic backgrounds and the few who attain the university status migrate to other places like Kitale scheme, Busia for fear of being attacked by the poor, illiterate youth gangs. The transfer of the educated has led to brain drain in the region leading to a vacuum in the strategic leadership, planning and implementation of educational and socioeconomic policies to develop the area. Most of educated group are teachers of P1 certificates, few University graduates, few medical officers, few engineers and technicians, accountants, managers who make the major human resource in the study area. Poverty drastically affects the children success in school due the nature of the poor households in which they experience hunger, fatigue, irritability and diseases. Housing is an effect of poverty as most of the households in Kenya and Emuhaya live in temporary houses made of mud walls, grass or iron sheets, earthen, floors, wood, prone to jiggers, fleas and poor sanitation due to lack toilets or latrines. The Nature of the housing system in this region can be compared to slum dwellers structures in towns that make up a third of the world urban population that live in poverty. (http://www.answer.com/topic/poverty).

According to the Kenyan constitution (2010) every person has a right to accessible and adequate housing and to reasonable standards of sanitation. This hasn't been achieved in Kenya especially Emuhaya district where nearly $90 \%$ of the population live in semi permanent mud and temporary houses vulnerable to the storm and heavy rains. The inhabitants are frequently infested by jiggers, fleas that infect them with diseases. The houses are also weak for Marauding gangsters who dig and kick through the walls taking household properties which are sold to make money for drugs and substance abuse by gangsters. In Emuhaya the effects of poverty on the poor households is so devastating and degrading especially for the youths, the old, aged, women, children and the disabled who rely on the working Male household heads to provide the basic Needs for the family. The sub-optional development of the production potential of the poor women and other vulnerable groups is a loss of their full contribution to economic growth and social development. The poor impose negative externalities such as drug trafficking, illicit liquor (changaa) selling and brewing, crime bagging, prostitution, spread of diseases such as HIV/AIDS and Sexually Transmitted Infections. Urban blight, social unrest and political instability all pre-dispose the effects of poverty of the Abanyole of Emuhaya district of Western Kenya.[37]

Street children is another effect of poverty in Emuhaya as the abandoned children move round funeral places, markets, celebrities looking for food. Some of the children have parents of economically poor; some are orphans, illegitimate and mentally impaired. The Danish government NGO-DANIDA based in Kenya has tried to rehabilitate them, plus initiating Micro and small scale enterprises programmes and development of youth polytechnics like Maseno, Esalwa, Emukunzi, Ebusiralo, Ematete for technical training skills to enable the youth attain self-reliant jobs. The area MP, Hon Dr Wilbur Otichilo works round the clock to reduce the poverty trap through donations, $19^{\text {th }}$ August 2009 he donated 28 seats to Luanda Markets shoe-shiners, in November 2009 donations of maize to over 4500 orphans and widows in 30 registered women groups, the MP build houses for the less fortunate members of the community giving them food supplies and household items. (Emuhaya News issue No. 5 January - March 2010). [46]

On gender and poverty we see the status of a woman abused. They work longer hours than men in every society to provide for the entire family household. The same woman's subjected to human rights violations through violence such as wife battery, rape, sexual slavery, gender based violence, emotional psychological traumas. This Nature of women disparity is experienced among the Abanyole in Emuhaya.

\subsection{Crime defined and it's effects on individuals and the society.}

Eshleman (2003) defines crimes as an act of violation of the criminal statutory law and a specific punishment applied by some governmental authority generally accompanies the violation. Criminal activities vary and even crime rates take different jurisdictions, with accompanying differences in the rates of enforcement in every state, and societies in the world. [32]

According to Thompson and Hickey (2002) crime is defined as an act that violates a criminal law and is divided into violent acts against persons and non violent actions against property. Thompson \& Hickey (2002:165) express that violent crimes are considered the most threatening because they involve offences 
against persons. They include homicide (unwilling taking of a persons life) aggravated assault (an attack with intention to inflict severe bodily harm) forcible rape (sexual intercourse against the victims will) and robbery (stealing from a person by the use or threat of force). This reflects on the atrocities perpetrated among the Abanyole people of Emuhaya district by the marauding gangsters who rob and kill innocent people in urban centres and villages. This year 2010 Emuhaya district residents witnessed several cases of murder, domestic violence, sexual abuse and harassment, rape, burglary, stock theft, assault, suicide, defilement, murder and many others that targeted men and women. The crimes are organized on high levels that the perpetrators are hardly arrested citing the case of Ebwali Secondary School Principal Mr Kolwa who was pulled out of his car at night and murdered next to his gate, the car hijacked and driven to the neighbouring Siaya district of Kenya. The angry inhabitants of Emuhaya demanded the renewal and beefing of the security, police officers to curb the insecurity in the region. Many criminal cases of murder have been reported at Ipali Market, Ekwanda market, Ebusikhale, Ebusakami, Kima, Esibembe, Ebuyangu and many other regions of Emuhaya accompanied with assault, rape, murder, gender-based violence and other human right violation are witnessed. [72]

Property offences and Non violent crimes which included burglary (unlawful entry with the intent to steal) is also common in Emuhaya as most of the unemployed youths break into shops, houses, stores, schools, stealing property. The main objective is to get money to purchase drugs like bhang and changaa (local beer) or busaa. Larceny theft, which is theft of stealing motor vehicle purposefully to use in burglary murder or criminal activities, is also common in the urban centres mainly targeting the African and Indian Businessmen. Arson crime which means intentionally setting fire on property which as common in Kenya during the early 2007 General Election where property and human being were set ablaze by arsonists supporting Orange Democratic Party(ODM) and Party of National Unity (PNU) led by the two Presidential Contenders Hon Raila Amollo Odinga and President Mwai Kibaki. Many lives were lost, animals killed and farms set ablaze. [72]

White collar crimes committed by professionals include embezzlement, fraud, inside trading, copyright, patent violations and the violations of the antitrust laws. The crimes are committed by people of high social economic status in Kenya. White collar crimes are highly organized by civil servants and the local Government Authority whereby large sums of money are siphoned from Government coffers without detection. The Goldenberg scandal is one example where millions of Kenyans money was stolen by key government leaders. Even the commissions set to investigate the case were also corrupted and to date no report has been made public. Mismanagement of investment like Nzoia Sugar Company, Webuye Pan paper Mills, Chemeli Sugar Factory, Kenya Meat Commission, Kenya Cooperative Creameries and other government institutions has drained the country's economic resources. From national level the same vices also extend to the study area of Emuhaya where the inhabitants of the area manipulated by the leaders and the public service workers through corruption. Most of the embezzlement of funds is done in Luanda market and other towns. According to investigations over ksh 2 million revenue collections in Luanda is misappropriated each month yet the workers go unpaid, no projects, plans on sanitation and development in the region occurs yet money is generated. It is notably believed the money goes to the officers pockets. Most Local Authority workers are seen drank throughout the month, with high standards of living in their households despite non payment of the salary incomes from the town Councils an indication of graft. [64]

Public order or victimless crimes are practiced through prostitution, illegal gambling, and illegal drug use. The crime does not involve clear cut criminal, the average citizens feels much less directly threatened by them (Thomson 2002) Public order crimes are rampant in Urban centres of Emuhaya like Luanda, Ekwanda, Esibuye, Kima, Maseno, Killingili where the Female youths seeks for a sustainability through prostitution. Women and men sell drugs like bhang, changaa (local beer) and other substance to the youths and older men to earn a living. There is gambling (isimbi) among the youths who at times commit crimes like fighting leading to murder especially when one has been fleeced of the money.

Juvenile delinquency involves children between 13-17 years old taking part in criminal activities like under age drinking, inhalation of shoe gum, running away from home and joining gangsters or street children. This group is very volatile they commit crimes against persons like murder, forcible rape, robbery and aggravated assault. The group goes further to organized property crimes like burglary, larceny, motor vehicles theft and arson. The team of these youths includes both boys and girls (Henslin 2000:181). [30]. Such groups are common in Luanda where the youths commit the mentioned crimes. There are organized gangs such as Luanda Town down of 42 gangsters stationed around Luanda Township, the Musumbiji originating from Kisa around Khumusalaba in Butere Mumias District. Most of the gangsters are aged between $13-17$ years whose purpose is to steal and murder the civilians who have investments or some in income. In 2008 a watchman in Luanda from Ebusakami Location was attacked and killed by being nailed 6 inch nails in his head, 2010 many watchmen in Luanda have also been murdered and the shops robbed. The same year 2010 the angry civilians from Ebusikhale, Ebuysubi and neighbourhood of Luanda torched a robber to death as the security (police and chiefs) watched. A motorcycle thief from Ebusakami around Luanda town was frog matched from his house in the broad day light slashed with pangas, beaten up transported on the same stolen motorbike to Epang'a and 
torched him to death. There are daily reports of rape cases, street children, taking gum in Luanda and funerals and other juvenile crimes in Emuhaya area. Professional crimes which include highly romanticized jewel thieves, safecrackers, counterfeiters, shoplifters, pickpockets and fences those who buy stolen good for resale can also are noted in Emuhaya of Kenya.

The professional criminal organize their lives around the work, plan their work, steal daily, associate with one another and avoid non criminal activities teach one another technical skills for committing crimes and avoiding detection. The incidences can easily be detected if the police depart and Provincial administration in the district as a whole take credit of curbing the falling crimes. The crime rate is escalating drastically each day but the police rarely serve the public but collude with the criminals to fear and insecurity. Kin (1999) show that the acting police Boyan Lewis in USA once said "We have convinced the public to support three strikes law lengthening criminals prison sentence to make judges tough on the criminals. Indeed crimes become a campaign issue as a political fear. Some people in Emuhaya go beyond bribing the police, courts and prison officials to avoid the judicial processes among the perpetrators. The released criminals again swing into criminal activities terrorizing everyone in the community. [33]

Professor Ted Chiricos of Criminology and Criminal School of Justice at Florida States University, studied crime and then concluded that television crime news on residents showed that fear levels were significant, regardless of whether the resident lived in high crime areas or rest. People living in places with low crimes rates and with high crime rates all had the same levels of fear (Kin 199:42) thus local media news in radios and televisions are reveal there is high levels of fear in the area of study. The Kenya Television Network (KTN), Citizen, Kenya Broadcasting Cooperation(KBC) always air news on the justice bench giving major crimes committed in Kenya making the citizens wonder who is next to be attacked by perpetrators of crime or violence. This violence creates fear of up to $80 \%$ in the country, Kenya National Poll Survey Results (KNPSR) (April 2009) data reveals that youths associated with looting and theft are 46.9\%, violent attacks and killings $31.6 \%$, crimes on blocking roads $29.8 \%$ general destructions of physical infrastructures $12.6 \%$ and those associated with atrocity such as gang rape $(9.0 \%)$. The majority of the youth who involve in crime languish in poverty, are joblessness in life, powerless, hopeless in life; the status in which $70 \%$ of the youths are in Emuhaya district. [33]

The gap between the rich and poor worsen each day in Emuhaya as crime and poverty increase. The legal duty of the police service is to be accountable and all the civilians. The police force ratio of 1 policeman to 1000 civilians (1:1000) has to improve to the recommendations of United Nations ratio of 1 police officer for every 450 citizens. There is need for capacity building courses and improved equipment, better welfare conditions for the law enforcers and the police to enable them maintain law and order to reduce criminal offences. It has been sighted that police are not quick to rescue the victims of crime because they are few, ill equipped so the criminals take advantage to cause conflicts and violence in the region. Greater availability of guns, pangas, rungus, clubs, boulders have increased violence levels in homes ant the entire community. At times the gangsters steal these equipments from the police armoury or collude with the police officer in organized robberies. The Kenyan government has been kept on the world record for disarmament of civilians and setting rounds of ammunitions on fire in the public. In Nairobi the year 2009 and 2010 over 5000 guns and thousands of bullets have been surrendered and set ablaze. This is an indication of insecurity and a national disaster that calls for proper legal framework and law enforcement improve security.

Bohm (1999) describes crime as an international gross violation of the criminal law or penal code, committed with defence or excuse and generalized by the state. He further lists the categories and the degree of crime according to the degree of severity of the offences, according to the nature the act prohibited or statistical reporting scheme and further divides them into felonies and misdemeanours in Kenya. Banditry survey reveals that organized armed robbery on highways were with gangsters attacking vehicles and stealing from passengers or motorists. Banditry activity by nature is loud and violent and is committed by a large group of offenders usually in rural areas and isolated family settings in the community. There are ranges of organized crimes in recent times in Kenya and Emuhaya which includes sophisticated Networks operating in big cities with leaders i.e. the Mungiki terror group of former criminal Maina Njenga. The groups involve the use and sale of addictive drugs, illegal gambling, murder, prostitution, rape, fornication; loan sharking has become their daily business. The Mungiki has been noted for mass killing of people in Central Province and interception of Matatu business operations in towns like Nairobi, Nakuru, Thika, Kakamega, rural areas demanding for money from the drivers and matatu conductors and even killing those don't tore to their demands. [66]

Drugs abuse is rampant in Kenya, it has been noted with great concern chagaa (local beer) is usually ill prepared, mixed dangerous chemicals such as Formalin, methanol spirit and jet oil has frequently caused death to the consumers. It is estimated over 200 people die of drinking changaa and illicit brew. In 2007, 11 people were reportedly dead after drinking jet oil at Esibuye market, several others including Paul Otiato of Ebusakami, a tax collector at Luanda market also died of poisoned changaa drinking in Emuhaya study area.

United Nations states that crime is optionally severe problem for the majority of the Nations in the 
world. Domestic crime has outstripped the control of most in individual nations and crime has accelerated beyond the current reach of international community. The report continues to state that crime is a serious impediment to harmonious development and it dissipates or misdirects the gains of economic growth and impairs the quality of life. Crime threatens the safety well being and personal integrity of us all. Criminality is reckless on environmental destruction, is alarming and is taken as a crime against the world itself. The Nuclear Weapons Firm situated in the West and East of the World emit dangerous nuclear fumes into space, factious and demonstrators burn smoke and plastic fumes into space, pollution of waters and air is wanting and none wants to address it as a problem. The developed states hardly address such crimes since it will affect their economic gains from these criminal trade and activities. The United Nations Charter on Human Rights has to be enforced to solve international problems on economic, social, cultural and humanitarian concern to encourage law enforcement agencies to help stamp out crime in the world. Banditry on land and the sea discourages travel, commerce and undercuts the efforts of farmers, herdsmen and artisans to establish a secure live hood. Studies have shown that outlawed criminals in certain states and regions shift their movement to other regions and continue to operate in the contemporary world taking the advantage of the isolated terrains in developing states like Somalia, Sudan, Algeria and Libyan known harbours for terrorism. The processors and traffickers of illicit drugs maintain base links hideouts in mountainous and forested countries.

United Nations (1991) depicted, that the interwoven expansion of transitional organized crime and the trafficking of illicit drugs provide the most powerful argument to debate for international cooperation in the criminal justice field. The study area of Emuhaya has several criminal cases emanating drug and substance abuse such as brewing of alcohol (changaa) in homes like Asiongo village of Ebusakami location, Ebusiekwe, Ebumbayi, Kaila, Musunga, Ebusiratsi, Ebutongoi and Emang'ali. Drugs and alcohol is sold by most of the law offenders and the poor citizen in the mentioned regions. The drunkards cause crime to the communities in many ways such as wife battering, separation, suicide, defilement, sexual harassment, assault and children abuse in the area. According to the United Nations areas where illicit drugs are harvested there is effects of addiction and lawlessness among their own population. [8] Gender based violence and street assaults, gang, warfare, domestic household strife such as women child physical abuse in closed doors are experienced due to structural nature relating to ingrained motion about the lesser status of women as well as stress due to emotional, psychological, social and economic pressure. Article 1 of the United Nations of Human Rights defines the four basic purposes of United Nations as to achieve international problems of economic, social cultural or humanitarian characterized in promoting and encouraging respect for human rights and fundamental freedom for all distinction such as to race, sex, language or religion. Article 2 of the United Nations (1948) on the Declaration of Human Rights States that everyone is entitled to social and international order in which the rights and freedom set forth in the declaration is fully seized. Among these rights is Article 3 on the right to life, liberty and the security of person. Article 12 provides that no one shall be subjected to arbitrary interference or attack upon his honour and reputation. Everyone has the right to the protection of the law against such interference or attacks and article 7 of section 2 stipulates that no one shall be deprived of his property. [8]

There are many people involved in crime in the world today. Some the most common crimes in the world and even in Emuhaya community among the Abanyole of Kenya are violent crimes like murder which is the unlawful killing of another human being with malice or aforethought. Manslaughter is the unlawful killing of another human being with malice. Aggravated assault which is classified into (i) with the intention of committing some additional crimes especially on burglary, robbery and rape the assailant use to achieve their intended goal. Forcible rape amount to an act of having sexual intercourse with a woman by force and against her will like a case of a woman who was raped, murdered and her vagina chopped off at Ebwiranyi village Luanda division of Emuhaya district in the 1990s. Robbery as the act of theft from a person, accompanied by violence, threat of violent or putting the person in fear is common in urban centres and rural settlements leading to underdevelopment. Markets in robbery stricken areas like Ebuyangu, Owemilabi, Mwiyekhe and the like have failed to develop due to frequent robbery. The crime of kidnapping which involves the unlawful taking and carrying away of human being by force and against his/her will, is not common in the study region but happens in many parts of Kenya especially in Nairobi , Coastal region and Rift Valley where passengers are kidnapped and robbed of their treasures.

Other categories of crime are property crimes which involves taking money property, but usually without force or threat of force. Some of the property crimes are larceny, defined as the unlawful taking and carrying away of another person's property with the intent of depriving the owner property. Burglary defined as the unlawful entering into the building and stealing. There are as cases of criminals in Bunyore who raid homes and murder residents without carrying property. Embezzlement is the wilful taking or converting to one's own person money or property, which was lawfully acquired by the wrong doers by reason of office, employment, or position or trust. This is common in public officers and the civil servants in Emuhaya. Grants, donations and government funds are misappropriated and siphoned into the pockets of the workers and some key leaders in the community. Constituency Development Fund (CDF) has previously been misused but between 2008 to 2010 the 
seating committee together with the member of parliament have done good projects on infrastructure, health, education, security and poverty reduction through micro-finance business enterprises by women and the youth groups. Arson not very common in the study area is the burning of houses or other buildings. This was experienced after the rigging of the 2007 Kenya elections where shops, homes and farms were set ablaze or torched during the conflict outrage across the state. During the violent period people were burnt in Eldoret church and farms, Nairobi, Kisumu, Mombasa and other towns many people and animals lost their lives to perpetrators violence.Extortion or blackmail is the criminal activity of obtaining property from another by wrongful use of actual or threatened force, violence or fear or under colour of official right. The crime selling of stolen property is also common in Emuhaya district urban centres like Luanda, Esibuye, Kilingili and Ekwanda markets. Most of these stolen goods are transferred to the recipients at night. Fraud which is the false representation of a matter of fact, whether by words or by false conduct or misleading allegation or by concealment of that which deceives and is intended to deceive and cause lethal harm. Forging is the fraudulent making of a false writing having an apparent legal significance and counterfeiting as under the federal law, falsely making, forgiving or altering any obligation or other security with intent to defraud. [16]

Crime of moral offences imply the violations of virtue in sexual conduct such as fornication, seduction, prostitution, adultery, illicit cohabitation, sodomy, bigamy and incest have also been experienced in the victims who harbour the information to the police, law enforcement groups including the human rights for fear of stigmatization. Public orders which make up the violations that constitute a threat to public safety or peace such as disorderly conduct, loitering, driving while intoxicated are also common in the study area. The most of the taxi drivers and touts are always drunk while on duty and at times cause violence or accidents on roads. The crime has hindered socio-economic development in the area in terms of health, education, infrastructures, water and sanitation, housing within the region. Organised crimes as such gambling, prostitution, loan sharking, narcotics and labour racketeering are highly practiced by the youths in urban centres in the study regions. The main underlying factor is unemployment of uneducated youths. Some of them engage in black market goods like sugar, textile, shoes, beans maize, rice, electronics from Uganda, White collar crimes and corporate crimes which are generally described as non violent offences committed for financial gains by means of deceptions by entrepreneurs and other professional skills and opportunities like environment pollution manufacture and sale of unsafe products, price fixing, price gouging and deceptive advertising. Misuse of resources has dented Emuhaya development, 1963 no factory or economic investment project has been established in Emuhaya by the government or the leaders in the region. The area is marginalized from economic development schemes due to corruption, lack of transparency and accountability. Occupation crimes which are the offences committed through opportunities created in the course of legal business or profession and crime committed by professionals, such as lawyers and doctors, acting in their professional capacities. In Emuhaya the police take bribes from the criminals, release them, the lawyers and magistrates of Maseno Principal Magistrate Law Court are also compromised not to prosecute the law offenders and terminate the criminal cases. In Maseno Hospital, a woman in August 2010 died after unsuccessful surgery by inerrant doctor and the efforts of the next of kin to pursue the prosecution were blurred due bribery and delayed due process in the court of law. Victimless crimes which make up the offences involving a willing and private exchange of goods or services that is in strong demand but is illegal like gambling, prostitution, drug law violation and sexual acts between consenting adults.

\subsection{The causes of crime in Emuhaya district}

Criminologists have tried to study the root causes of crime and how it might be prevented throughout history and even tried to explain what causes abnormal social behaviour including crime since the time of Hammurabi the law given in Babylon 3700 years ago. The studies done around he world reveal causes of crime are anger, jealousy, revenge, or pride. The desire for more or material gains, expensive belonging or material leads to property crimes such as robbery, burglary, white collar crimes and auto theft. The desire to control revenge or power leads to violent crimes such as murder, assault, and rapes. These violent crimes usually occur on impulse or the spur of the moment when emotions run high. Property crimes are usually planned in advance by those who are in need of money and materials to sell for income gain to support their lives and families. In 1970 to 1978 property crimes in America rose from 7.4 million to 11 million while the Number of people placed in state and federal prisons grew from 290,000 to over 1.2 million. The study of 1998 revealed that longer prison sentence had little effects on discouraging criminal behaviour. [9]

On parental relation Clecky (1980) describes the cycle of violence or pattern found in family histories as where people grow up with abuse or anti social behaviour in the home will be much more likely to mistreat their own children who will in turn follow the same pattern. Neglected or abused children are likely to cause crime, sexual abused in childhood often leads the victim to become sexual predators as adults and these progress through generations where the cycle of socio-patchy keeps repeating itself. Heredity and Brain activity, studies have shown that antisocial disorders and influence over crime to show that crime can also be generic. Some research shows identical twins had the same animal behaviour as their biological parents. Then to the adoptive 
parents Hare (1986) psychologist identified connection between brain activity and antisocial behaviour and formed out that experienced brain reactions to dangerous situations than most people such kind of brain function leads to greater risk taking in-life, with criminals not fearing punishments. The researchers have used Computerized Tomography (T scans), Magnetic Resonance Imaging (MRI) and Position Emission Tomography (PED) to link the brain activity and a tendency to commit crime revealed that neurochemical substances in brain triggers body activity and hormones influencing criminal behaviour. The study revealed that the people who have low levels of dopamine in the brain commit violent crimes and aggression. Hormones are body substances that affect how 'organs in the body function. Education levels of the society are a cause of crime. Most of the crimes committed by like burglary, robbery, by automobile theft drug trafficking and shoplifting are conducted by criminals of poor educational backgrounds, their employment histories consisting of low wage jobs with frequency periods of unemployment. Employment at minimum wage or below living wage does not deter criminal activity. [9]

Peer influence, influences the group to commit criminal activities. Youths who live in towns and rural setting possibly school dropouts are bound to take drugs and join gangsters to commit crimes in the community. Drugs and alcohol impair judgment and reduce inhibitions giving a person chance to commit a crime. Family household heads that cannot provide for their children man high rates of crime. Drug and alcohol, a social factor can accelerate one to develop an antisocial behaviour since they impair judgment and reduce inhibitions (socially defined rules of behaviour) thus giving a person a greater chance to commit more crimes. Some of the violent crimes caused by the group are murder, assault, sexual abuse, gender based violence, robbery, and other vulnerable targets to criminal activities. Easy access to weapons like pangas, guns and blunt objects provide a means of committing crime. Most bank robberies in Kenya are organized with robbers armed with pistols and guns. Access to information technology also ease's the work of criminals to commit crimes. [9]

Urbanization brings in place different types of antisocial behaviour who involve in crime in the region, city problems especially slums like Kibera, Korokocho the suburbs where the poor engage in crime like alcohol brewing and selling, and drug trafficking in Kenya. Urban centres in Emuhaya such Luanda Kilingili and Esibuye have all types ethnic groups dealing in such business activities and this has also increased crime rates like murder, robbery, burglary, prostitution, child abuse, illicit sale of drugs changaa and bhang, price fixing, corruption and the like in the area. The researcher in Chicago in America show that people of racial background living in urban centres were profoundly influenced into crime due to poverty and the social instability of their neighbourhoods. Poor social and economic environment produce all types of crimes. Criminologists Edwin Sutherland (1883-1950) shows that criminal behaviour was learnt through exposure to crime through relatives and peers as they socialize together. Gender disorder in the neighbourhood leads to an increased antisocial behaviour and eventually serious crimes like murder, robbery, rape, broken families, widows, may cause child abuse, assault each other, adultery, spread of diseases such HIV/AIDS, prostitution causing disorder among the citizens of in safe streets. There are crimes such as public drinking panhandling (begging for money). Most o the causes of crime are due to poverty, peer influence and social relationship with the people who commit crime in the society. [9]

\subsection{Empirical Studies On Poverty And Crime}

\subsubsection{The relationship between level of employment and crime}

The Shorter Oxford English dictionary (1993) defines employment as an action of employing, the state of being employed, the service of work or an activity in which a person is engaged. The opposite of employment can be termed as unemployment as defined by the world Book Encyclopaedia (2001) as the state of a person who is out of work and actively looking for a job because of illness, or mental or physical disability, nor refer to people who are attending school or keeping house, such people are classified out of the labour force rather than unemployed. [11]

According to Uganda Poverty Eradication Action Plan (PEAP) (2007/8), The Ministry of Finance Planning And Economic Development report (2004) states that employment is obtained in big towns and separates the youths from the aging parents in rural areas and there is brain drain of the cream of Ugandans who migrate to Europe and America looking for greener pastures. The report continues to show that the World Banks Structural Adjustments Programme (SAP) and Poverty Alleviation Strategy (PAS) and the Economic Reconstruction Programme (ERP) known as privatization policies have no direct role to the suffering rural people and international policies do not consult the grassroots who are planners and implementers of the well being.[6]

According to Owolabi (2006) examining the human theory states that the productivity increases the level of work by providing workers with specific knowledge and skills for farmers, factory workers, transporters investments in form of education and training increase the level of productivity. The theory has close relationship with employees who must be educated, trained in skills and knowledge to meet the labour market demand both at rural and urban levels. On the same motion we see Kenya encouraging National Economic 
Development through education since 2003 saw free primary education started followed with free secondary education in 2008, where primary school pupils are given a grant of Kenya shillings 1020 while learners are allocated Kenya shillings 10650 annually to carter for fees and instructional materials. The government strategy was to increase the quality of the human resource in the country. [16]

The workers earnings increase with the level of education where starting point of unemployment is higher and increases steeper as the level of education increases. Educational skills and training is expected to lead to higher productivity of the workers, as making of critical decisions that involve careful analysis of situations in the work place and also make the organization to achieve its goals and objectives. Owolabi (2006) studies show human resource has to be a pre- mediated design, oriented towards the future and devised to achieve goals by optimal means and is the organization's joker to help fill unexpected vacancies, replace positions created through natural attrition, while opportunities created by product expansion or addition and to develop and return valued staff.[16]

The human resource theory on demand on labour market surpasses the Kenya decisions when they do not implement strategic plans and legal policies on employment of works and become arrogant as the Minister for Finance reported in the local Daily Nation Paper (2003) stating that "the government will not immediately employ teachers to support the free education programme launched on Monday. It will also not disburse Free Primary Education funds (FPE) to schools until next Month or March", the minister for Education George Saitoti said. He retaliated that employing teachers required funding which was not included in the current budget, (Kenya Daily Nation January 11, 2003:5). The level of employment is low and even those available have low wage pay especially in agriculture, small business enterprise, local market workers and casual workers like watchmen have a salary margins Kshs. $1000-2000$ while the rest of the categories earn to a maximum of Kshs. 5000. The next class is teachers and civil servants who command the economic power of Emuhaya the study area, according to the statistics, most of them earn between Kshs. 15, 000 to 25, 000. They have to meet medical, education, welfare, taxes, nutritional provisions of their households. This income does not even support the basic requirements standards of the people leading to several criminal offences in both the household and the society.

The people from the poor households engage in criminal activities like robbery, corruption, bribery, selling chang'aa, bhang, miraa, tobacco, stealing from the neighbours and other human rights violations. This is due to restrained incomes and unemployment levels in the republic of Kenya. Investments Programme for wealth and employment creation $2003-2007$ states that the rate was approximately 7 percent by 1986 ; it had increased to 6 percent and continued to rise to 25 percent in 1999. The unemployment in the same period was acute at 94 percent by 1999 and Kenya was estimated at 14.6\% globally. However the unemployment is a significant contributor to the existing class of Kenyans who live below the poverty line.

\subsubsection{Relationships between family structure and crime}

The definition of a family structure by Parillo (2002) depicts it to portray the golden age of a family as consisting of several children and a harmonious married mother and father, all working together, sometimes aided in life by grandparents based on spiritual values passed on the to children. Family structure can also be defined as the composition and membership of family operations and the patterning of relationships among individual groups. Others state it as a basic unit of social structure which vary from time to time and can be categorized as bourgeois family, nuclear, extended, single parents, child headed, blended family (when divorced remarry) or widow remarries, consensual union (living together but unmarried) some sex union, homosexuals, empty family nests with grown up children who self recount, complex families). According to the New Shorter Oxford English dictionary defines the family is a group of people living as one household including parent and their children boarders' servants that end as an organization unit of the society.[17]

Parillo (2002) show that family structures in general have changed considerably since the end of World War I and World War II due to societal trends, legal reforms and increased proportion of women in workplace. The family structures have contributed to higher roles of divorce and child suffering in most societies in the world. There is continuous entangles, husbands abused by wives, parents abused by children and brothers abused by each other. A study conducted in America in 1996 examining 7000 couples who participated in the national survey on the family households found out that most couples engaged in similar physical violence during marital fights. Parillo (2002) brings out the issue of domestic violence and abuse in households whose income cannot meet the households' basic needs.

Another researcher in 1998 National Elder Abuse issue report shows that over 450, 000 elderly persons aged between 60 years and over experience abuse and neglect in domestic settings of which the perpetrator were family members of which $2 / 3$ were adult children or spouses. He further elaborates that elders are the most vulnerable to abuse; women of over 80 years suffering from dementia and other diseases, with communication problems, difficulties in hearing, seeing, immobility, loss of sight and inconsistency are discriminated. The plan 
of taking care of elders in Emuhaya is bleak. Most of them languish in poverty, poor sanitation; suffer from hunger and starvation, no medical care thus live vulnerable lives.

The family households with divorced parents suffer low levels of standard of living, some experience economic hardships when they move to the neighbourhood, go to inferior schools, receive poor nutrition and health care while older children are stigmatized among the peers. "Energy Child Support Obligation" entered a new era in the 1977 when the federal government began operating a computerized directory that lists energy person newly hired by every employer in the country, enabling federal state investigators to track down parents who owe money to their children. The children from divorced homes have higher rates of delinquency problems in peer relation and school performance from the past divorced parents. Children especially girls cannot control their sexuality and making emotional commitments. Paul Amato and Bruce Keith research show that children of divorced parents are less likely to graduate from high school, have low earnings, dependent on welfare and are likely to marry at an early age; daughters have children out of wedlock and practice divorce just as their parents. Divorce has long term and short term implications on mental and physical well being of the family. Divorced women and men face depressions and may be subject to high rates of accidents, homicide, suicide, alcoholism, drug abuse, anxiety, poverty, low income, child abuse, street children, and juvenile delinquency. Children with divorced parents live in depression leading to low education, school dropouts and other socioeconomic conditions as revealed in the study of Mulinge (2008) on absenteeism and academic performance of learners by HIV/AIDS in selected primary schools in Mulaa zone Kibwezi district Kenya.[19]

The study of Mulinge (2008) shows that in 2003, there were 13 million HIV/AIDS orphans globally within Sub Saharan Africa contributing to 5 million of the vulnerable children in the world. According to the report HIV/AIDS had spread faster and the death rates have gone high to 37.8 million. In 2003 Sub Saharan African female population translates to $2 / 3$ of the youths living with HIV/AIDS infection. Women cannot negotiate for safe sex or turn down unwanted sexual behaviour. The adolescents are at high risk of infections due to low income, unemployment, lack of security, property, as such they engage in sexual crimes. This lead to violation of the legal framework of the governments and human rights as far as human economic rights of the United Nations are concerned. [19]

Tanui (2008) studies show that orphans are not only deprived of basic needs like food but also education, due to poverty and lack of caretakers so they likely dropout of school. Polygamous and extended families do set major family objectives to raise their standards of living of households but they end up hopelessly in poverty and crime. There is jealousy and rivalry on the attention of mother and father which hampers the smooth development of the homes and the family. In most families boys are favoured to attend school and encouraged to high levels other than girls whose academic achievements are compromised. Most of the property inheritance and ownership in households within Kenya, Emuhaya study area are mostly left for men and not women.

Apicha (2007) shows girls who re violated educationally which cause them to result to early parenthood leading to street children and destitute who end up becoming thieves, beggars, smugglers, gangsters, commercial sex workers, to earn income for their daily basic provisions. Family structures are faced with hunger and starvation due to social economic problems leading to deep poverty. The 1985 publication on ending hunger, defines hunger as a desire for food. Poor households in Kenya especially Emuhaya suffer from extreme hunger and starvation leading to malnutrition in children as the youths and adults are forced to use criminal means for survival. Lamentations of this kind are common in Emuhaya villages: "Today I licked the container that the smashed potatoes were in and tonight before bed. I lick the sides of the container ". Every year 13 - 18 million people die of hunger and starvation, every 24 hours 35,000 and over 24 minutes 18 people die most of whom are children less than 5 years. According to the research the World food Organization report states that by 1985 more people died of hunger more than the combined death toll of World War I in 1918 and World War II in 1945 and about 40\% of the worlds hungry are children estimated at 15 million each year. Orphans the age of 16 - 17 years who have lost both parents continue to pose challenges to households; they suffer psychological and emotional vulnerability in addition to the material deprivation.

The government strategy for orphans and other vulnerable children as, those living on their own including street children in towns, those who are abused, neglected, abandoned, children who are abused, neglected, children in need of legal protection and alternative family care, children in hard to reach vulnerabilities and children used households where they are facing significant physical, mental, social and emotional harm.

These brings the attention of the government economic strategic plan to be implemented at local or rural level to help improve the welfare of the children and the youth to step out of poverty by being industrious and innovative . The disabled in family household suffer relative income poverty in addition to reduction in their quality of life, social stigma experience and more limited access to services. The issue needs address on the extent to which the disabled people are able to meet their specific needs such as equipment, education, 
employment, healthcare, good housing, safe water and sanitation. Indeed the extent to which the specific disabilities are currently preventing economic participation or reducing productivity is wanting in the study area. In accordance to Uganda budget (2003 - 2004) show that the Poverty Reduction Strategy Paper (PRSP) report 2001 indicates that inequality in Uganda has increased consumption gains as in equality distributed across the population, with the richest having experienced the largest rise in the living standards. Poverty continues in Uganda as a rural phenomenon with 96\% of the poor living in rural areas in 2000 (Uganda Debt Network October 2003:4). The cases can be expressed as a common factor in family structures in Emuhaya study area. There is rampant issue of destitute and illegitimate children from poor households in urban centres of Emuhaya who are homeless, hopeless and powerless who sleep and move in Emuhaya study area like wild beasts. They inhale shoe gum, petrol, eat from well wishers and indulge in criminal activities like robbery, rape, substance and drug abuse, burglary, riding train, bicycles in dangerous positions, assault, defilement of girls under 14 years, hawking without license, stock theft, murder and manslaughter, keeping goods without legal authority. This concludes the statement that poverty and children deprivation within families is the main cause of crime.

Muga (1997) stated that society is commitment to eradicate poverty derives its moral justification from the enormous toll of human suffering that poverty exerts as well as from the obvious injustice and the inequalities implied in the nation's income. According to the rationale the elimination of poverty stems from output foregone or not produced as a consequence of poverty's negative input upon individual productive potential and from the fact that the existence of poverty coupled the society to allocate each a significant fraction from its public sector resources to combat poverty induced social ill such as crime, drug addiction mobility ignorance and slums.

Freyman (1996) states that in Africa 70\% of employment in Agriculture are women who play a major role in taking care of the children, the sick, elderly, gathering wood, preparing meals, housework, taking part in community affairs, fetching water and carry $70-80 \%$ of the agricultural work planting, weeding, watering, processing and future households food storage. This is violation of human rights according to the Kenyan constitution $6^{\text {th }}$ May 2010, women and men have the right to equal treatment including political, economic, cultural and social spheres. This has been grossly violated as the men who do the same jobs in agriculture are better paid than women in households who are also overworked at the same time exposed to gender based violence in homes. [29]. Emuhaya has high population with household families which are extended, single, nucleated, divorced, separated, children headed and clustered together on small land holding with little or no investment as the Vihiga District Development Plan (VDPP) 2002 - 2008 on the Effective Management for Suitable Economic Growth and Poverty Reduction (EMSEGPR) "that high concentration of population is witnessed in rocky areas such as Maragoli hills and the swampy parts of Luanda Division. This has aggravated the land poverty as land subdivision is rampant.

According to the Vihiga District Development Plan 2002 - 2008, Republic of Kenya; Luanda division of Emuhaya district had a population of 102, 084 people with a density of 1035 people per $\mathrm{km}^{2}$ while Emuhaya had 76, 457 people with a density of 1025 people per $\mathrm{km}^{2}$. The area is densely populated with a total fertility rate of 5.5 percent. The report continues to reveal that the households' access to piped water was 200; portable water 22,000 , numbers of permanent rivers 4 , wells 50 , protected springs 200 , boreholes 24 , and house hoods with roof catchments 99,188 and the average distance to the water points was 1 kilometre. Up to today the objectives of these strategic plan has never been realized and even those which had been established have collapsed. Other factors which affected the households and social family structures was urbanization and industrialization that has made families become smaller, with few children, kinship has become less important and the growing emphasis on individual rights has led to redefinition of marriage as a source of fulfilment rather than a social, obligation or an economically rewarding partners.

\subsubsection{The relationship between social support and crime}

Social support involves financial and material support to the vulnerable poor households for them meets the socioeconomic challenges. In 2003 the Uganda National Strategy addresses the mitigation on factors of susceptibility of HIV/AIDS infections as well as minimizing the burden of the disease at individual community and national level. The common people include Voluntary Counselling and Testing (VCT) policy which has tested over 70, 000 people and the OVC policy to target the poor vulnerable groups thus aiming to address the needs of an estimated 1.7 million of orphans. This initiative helps to reduce the HIV/AIDS prevalence within households. In Kenya, Pathfinder International has supported reproductive health, family planning and training to Kenyan citizens since 1969. They have worked closely with over 60 Non governmental and Community Based Organizations, government agencies, public and private sector institutions to reach the poorest communities with reproductive health information including contraceptives, counselling materials and childcare services. (http://www.pathfind.org). It is estimated that HIV prevalent among the young and middle aged Kenyans (the most productive segment of the population) die of HIV/AIDS. An estimate of 700 Kenyans die daily of HIV/AIDS related diseases or causes leading to orphans and women headed households even more 
vulnerable to poverty. The burdens of HIV/AIDS, malaria and water borne diseases weigh heavily on both the country and Kenyan families affecting income. Food security and development potential has made Life expectancy to be down by 46 years from 59 in 1989.

Over the past 30 years, poverty has been on the rise in Kenya. Poverty seems to be the paradox in a country that has the best development economy in Eastern Africa. With sector and substantial foreign exchange, earning from agricultural exports and tourism Kenya is still a low income country with per capita income of about US dollars 360. It is ranked 148 among 177 countries in United Nations Development in terms of life expectancy, educational attainment and standards of living. (Http//mhtml: file//Bourne 14/cuttttttt/Enabling the rural poor to overcome poverty in mht) To address the above problem IFAD has invested a total of US dollars 1115 million to loan financial programme and three grant financed programmes supporting the government efforts to reduce the rural poverty. Investments include US dollars 18 million under Belgium Survival Fund Joint Programme (BSFJP) and also US dollars 68 million from other donors. The government of Kenya and project beneficiaries have contributed about US dollars 56 million and US dollars 11 million towards helping the needy programmes among the vulnerable in Kenya. [20]

World Bank funds agricultural projects and establishes projects in poverty stricken regions. Most of the support projects and programmes are appropriate technologies, increasing small hold rings on livestock production, promoting of farms income generating activities for smallholders and encouraging community participation. Kenya Women Finance Trust (KWFT) a micro finance institution helps to improve the women income through saving and credit. The institution supports over 40,000 women members throughout the country. It has intensified its focus in rural areas among the poor households, remote and marginalized areas. Social support can also take a form of sharing domestic tasks in the households mostly abused by men due to conflicting gender roles. Newman (2002) uses the conflicts theory to show how women have been abused in households. They work for free outside the main stream economy and if women they were to be paid the minimum wage rate, then it exceeds the men's payments. The Kenyan government put in place in 2002 signalled a major political change in Kenya as indicated in the Economy Recovery Strategy for Wealth Creation (KERSWC) which includes Kenya Poverty Reduction Paper (KPRP) (2001 - 2004) to improve on governance and reduce corruption, promote better health services and education, promote structural reforms for liberalized economy, to achieve equitable distribution and conservation of the Natural resources and promote the private sector. These programmes are subjected to support the poor households support them out of poverty sustainable development. IFAD supports the Kenyan government to reduce the poverty through integration of small holders producers and finance world for all her labour as mother and housekeeper, childcare, transportation, errands, cleaning, laundry, coking, bill paying, grocery shopping her yearly salary would be over average salary of male full time work. (Newman 2002: 393). Despite significant shifts in attitudes towards gender roles and the accelerated entry of women into paid labour force in the past few decades, housework continues to be predominantly female as they take the entire household and employment tasks. [18]

\subsubsection{The relationship between level of education and crime}

Herslin (2002) expressed that education is one of the main approved ways of reaching the desired goals of an individual in the society. The children of the poor are ill prepared for the bewildering world. They confront with conflicts sharply within their background. The schools where the poorest children attend are inferior to the school the rich and educated people take their children. These barriers contribute to school dropouts, blocking them legitimate avenues for educational advancements leading to street children, robbery, burglary, selling drugs, pimping, prostitution, gambling and other income criminal activities. Education has the strongest effects on economic status of the households. The people who have not completed high school experience higher poverty rates than those completed. Those who go beyond high school (college or university) get better employment and income. Research has proved that parental involvement in educational process is a key element in motivating educational achievements of their children especially through Parents Teachers Association (PTA) at school levels. (Thompson and Hickey 2002) [12]

Thompson and Hickey (2002) warms in his research study that the benefits of education are too high and invisible if the individual or person who achieved an education defile their home communities by going for greener pastures. This type of brain drain leads to leadership deficiency within the community. There is no one to strategic plan and make decisions all sorts of development in the region. The parents need to encourage the children to go to school a prospect of a good future. The human rights legislations stress for equality rights, welfare rights and economic rights that require proper of education against poverty and starvation. These laws remain meaningless to the people of Emuhaya they have no hope of meeting the socio-economic challenges like education, food, shelter, land and healthcare. There is a big contradiction between the equality rights that guarantees equal citizenship, equality before the rule of law. There is segregation in resource distributions in all sectors and arms of the government of Kenya. In education the poor attend rural school while the middle class and the rich families attend urban model schools ending up with quality education compared to the poor student. 
An example is the Kenyan Parliament which is full of sons and daughters of former politicians in the governmental leadership. The educational gap between the poor and the rich Kenyans is constantly widening everyday. [12]

Bhorat and Leibbrant (2002) show the education has a paramount role in redeeming poverty, because it contributes to improve earnings of the poor both in the job competition and earnings in a statistic labour market and a source of growth and employment. Consequences of growth inequality in education resulting from certain age cohorts who never attended education pass the same to their households from generation to generation. Technology has increased the educational fields and economics enhancements as the people can communicate, trade, study and access all their needs through the internet, computers and phones due to globalization. But the dangers of globalization are that it promotes white collar crimes among the system through fraud of public funds and misallocation of government budgets leaving the citizens vulnerable. United Nations (1991) asserts that new technologies are used in confiscations of tribal land, frustration of land reformers or poisoning of labourers by chemical insecticides.

Schmallenger (2004) shows the effects of family divorce ruins the educational levels of children and the socio-economic status their households. The children of divorced parents live in depression and frustration helping them to indulge in criminal activities. Divorce and separation creates avenues for child crimes like juvenile delinquency rape, early marriage, stealing, gambling, child labour, murder, incest, assault within the community. Education improves the economic status of the community and the household. [9]

According to Owolabi (2006) employment of workers goes with skills and training and leads to higher productivity, making of critical decisions that involve careful analysis of situations requires personal higher levels of education. As the saying goes nothing comes on a silver platter, Kenyans and the people of Emuhaya must take relevant strategies that will reduce poverty situations. He further stipulates that the current educational qualifications are sought to modern sector jobs and without leads to unemployment. Poorly educated societies have numerous criminal activities like chang'aa and busaa selling, drug abuse and serious violation of human rights while the educated take up sophisticated crimes of corruption, bribes like the Kenyan police, the judiciary taking bribes to change a case and delays of the due process to destroy the case evidence. The workers violate the work codes and franking of the government money services leading to poverty. [16]

\subsubsection{The relationship between property and crime}

Property as defined by Oxford Dictionary (1993) as a thing belonging to a person or persons or possessions especially real estates, housing, shares and investments.[11] Perkin (2005) sees property as established titles to ownership use and disposal of factors of production and goods and services that are enforced in court. In accordance to United Nations Universal Declaration of Human Rights article 3 that everyone has the rights to own property alone as well as in association with others and no one shall be arbitrarily deprived of his property. The Kenyan 2010 constitution recently ratified, in chapter 4 stipulates that every person has the right either individually or association with others to acquire and own property each of any description each in any part of Kenya. [34]

Marcus (1999) said the material wealth of a society is determined ultimately by the productive capacity of its economy that is the goods and services that can be provided to its members. The productive capacity is a function of the real assets of the economy like land, buildings. Knowledge and machines are used to produce goods and the workers whose skills are necessary to use those resources. Financial assets certainly contribute to the wealth of individuals or firms holding them in bonds or stocks, deposits, life insurances, pension reserves, corporate equity mutual shares and debt securities. The Kenyan inheritance laws affect everyone who owns property in Kenya. The law of succession Act and civil produce apply to all cases of intestate of testamentary succession in Kenya. The Kenyan constitution guarantees that foreigners of different nationalities or religion are not treated differently to Kenyan on inherits, buy and sell property in Kenya. There is the law of succession of both moveable and immovable if the owner dies. Http:/www/globalpropertyguide.com/Africa/Kenya/inheritance. [59]

The Kenyan law determines ownership and through courts where by property ownership and how its distributed between spouses and next of kin is verified, in case of land, title deeds are used the heir is given whether widow or children or suitable guardian. Shares ownership in Kenya on real estate prices is still souring it can be difficult for first line buyers to get their feet on the first ladder. The prospects for the middle class Kenyans buying a home can seem very daunting due to high house prices, unachievable deposits and lenders looking for low risks. (http:/propertyleo.com/article.php?-id=15) [21]

According to the above research it indicates that the poor with little income remains at the lower ladder on property ownership in Kenya. The cash deposits are difficult to find, securing mortgage of $20-50 \%$ of the purchase price and monthly costs of $50 \%$ are not easy for most of the people living in Kenyan communities to achieve. In the Kenyan communities most of the property is owned by males and not females in accordance to the cultural rights. But there is a wave of change as both men and women own land, houses, cash deposits, 
insurance, stocks, bonds, pension schemes and shares. This is a proof of equality in property ownership in Kenya though it has not picked up well in the local communities who are still holding on the traditional rights of property ownership. Women's land rights in Uganda both the inequitable legal structures and traditional practices. Data shows the female headed households have fewer assets especially when children grow up. (Uganda Poverty Eradication Action 2004/5 - 2007/8)[6]

Colander (2004) shows that markets require the establishment of property rights. Establishing property rights is a difficult political process. African countries have problems for they establish property rights with an underdeveloped political process. Political stability limits internal investment, income distribution in many developing countries is highly skewed, and there are few rich people and an enormous number of very poor people while the middle class is often small. Colander (2004) argues that the inequality among community members leads to higher levels of savings by the rich and therefore has no significance advantage for developing countries. The statement relates to Kenya where they have immersed lots of land, machinery, vehicles and other household properties whereas the majority poor have little or no land with few household assets. Income from households savings are part of spending unit income property which is not consumed and all expenditure made by spending limits for purchase of durables and jewellery was treated as part of the savings. Household's investments defined as the allocation of households' savings among different assets for future return or benefits are grouped into financial investments, physical and net charge in claims. Financial includes fixed accounts, fixed deposits, governments bonds and securities, share and cash balances in current and cash in hand. Insurance life premier, provident fund contributions, widow and orphans pension scheme and loans guaranteed are all forms of investments. [40]

In the federal times much of the land was held communally, it belonged to everyone and everyone used it, was common land and community resource. The land tenure system in the 1960's and 70's decided to allocate parcels to individuals as land ownership which has now created conflicts between the rich and the poor in Kenya and Emuhaya study area. Indeed the evolution of the economy brought landholders who determined the use of land and rent it to other individuals. Many people in Emuhaya believe that the property rights were unfairly distributed and even state that those who own most property in this region were rest legally acquire. The concept of private ownership must exist and must be accepted by individuals in the society. Lack of property to the citizens of Emuhaya has prompted property crimes like stealing, land disputes, burglary, stock theft, organized crimes where the criminals sell drugs to purchase property and basic household needs. It is in this respect the research wants to establish and make recommendations on how to curb crime in the study area.

\subsubsection{The relationship between financial standing and crime}

Financial standing of the people is born with different skills and talents. They group up in different schools, districts, and control different amount of capital and natural resources and encounter different prejudices. These differences by themselves may cause income to vary, as people go through life, the decision they take cause income to vary still more as a result earn nothing while others earn millions of dollars a year (kulkarni 2005:409)

World Bank (2003) show the low income level was US dollar 1860 for family household of 4 people which is about $30 \%$ of their income in the world. The report continues of state that it used US dollars 1 or 2 per person per day as measure of global poverty. Two dollars per day or US 2920 per year for a family of 4, is just $16 \%$ the United States Government. Over 2-8 billion (56\%) of the world's population live on less than US dollars 2 per day and 1.3 billion people $(23 \%)$ of the worlds population live on less than 1 dollar per day. Sub Saharan Africa is the poorest region of the world, where half of all the people live by one US dollar a day or less. In Ethiopia, 4 out of 5 fall below this threshold. It is estimated the percentage of poverty will fall from 76 percent to 70 percent over the period $(1990$ - 2015) but with rapid population growth in the poorest African countries the absolute number of poor people is projected to rise by nearly $60 \%$. [74]

Mauri (2004) show those households saving are part of the spending unit for purchase of consumer durables and jewellery and was treated as part of savings. The relationship of these statements and the income in Africa households' shows that poverty situations will persist as there are no savings, investments as some of income for the wages reaped is consumed on the same day and not enough to subsidize financial needs of the entire household. The investment as grouped into financial investments, physical and net charges in claims. Financial investments include savings accounts, fixed account and securities, share and cash balances in current account and cash in hand. The study in relation to the Emuhaya study region in Kenya has no levels of investment in from of skilled human resource, capital goods, household investment, and unemployment to reap minimum income to raise the household standard of living. The Emuhaya has developed a theory which shows the income and consumption as something from hand to mouth a form of handout. The people live in the now and not the future. [62]

Households that are largely headed by females, and by adults with low educational attainment or deriving most income from agriculture are more likely to be poor than others. Households with larger infants 
and children have a lower level of consumption and thereby a higher probability of being poor. Female headed household in urban areas are poorer than other similar households. The education of both households headed and of the spouse appears to be an important determinant of poverty, wage workers, whether in public or private sector are better off than informal workers such as unpaid family workers (Kenya Investment Programme March 2004). These reflections tell us that the relationship between household incomes in Kenya both in the rural and urban cannot sustain the better standards of living and financial standing of the households in Kenya and Emuhaya, region with an increase of criminal.

Emuhaya New (March, 2010) show that investment the business fraternity leaders at all levels and potential investors should focus on economic development. Simple business were captured in the study including brick- moulding, fish farming, diary goal and cattle rearing, bee- keeping poultry -farming, horticulture, greenhouses fruit and vegetable growing, small-scale business, was held in Emuhaya under the sponsorship of Kenya investment Authority to promote trade and commerce. This is and Economic stimulus Programmer (ESP) to help create employment and other source of household income to improve their financial standing. [46]

Parrillo (2002) show that in the past women often depended on men for financial support and so might hesitate to terminate even a miserable marriage, but now many have the ability to become self supporting. The statement relates to the roles of women in Emuhaya whose changing roles have made them take up the financial, management and decision making in homes. They work on small business holdings, agriculture and casual labour for there wage incomes. Households heads who does no have proper financial standing than their spouses have had family struggles leading to divorce, separation child abuse, assault, and even murder commonly record in Emuhaya study area. The Divorced widows, husbands with low income result to illicit alcohol (Chang'aa) drinking and tobacco smoking which they openly say reduces stress depression giving their freedom to relax and forger the attributions of poverty. Most of them drink to take night hours and reach home when of poverty. Most of them drink to late night hours and reach home when to find every household family members are asleep. [17]. Young women join the commercial sex world to gain financial support her family and the family. Ameir (2007) shows sexual exploitation particular affects young girls, poorest women and young men. The poor view other types of culture change as positive. Negative and positive live hood impacts will vary between situations among people, overtime and on the extent on which people, over time and priories are able to influence the poverty are able to influence the poverty process.

The land tenure system is discriminative on women thus they have to seek for decision for land usage from their husbands to turn into income generating enterprises. Though the portions are too small to sustain crop farming and livestock production the income level of the homes, some peasant farmers have livestock on zero grazing for dairy, poultry for meat and eggs and vegetables gardens whose produce is harvested and sold to buyers in the local market centres. Some of these products are stolen by errand thieves who steal them both at night and day for their basic needs. Uganda budget (2003 - 2004) show that the poor performance of households was attributed to low production and yield, poor prices in adequate incentives to expand production, lack of markets, environmental degradation and insecurity issues which are common in the study area. The Uganda government plans to modernize the economy by eradicating poverty through multi-sectional interventions. [5] Kenya should have current legal and administrative infrastructure for financial management practice in the government enshrined in the legislation that directly or indirectly affects the budget transparency, accountability and implementation to raise household incomes in Kenya and the study area to avoid poverty and numerous criminal offences.

\subsection{Introduction}

\section{Research Methodology}

This chapter deals with the methods that were used in the research to come up with the findings of the study. The chapter includes research, design, research population, sampling, and sampling procedure, instruments, data analysis, ethical consideration and limitation of the study.

\subsection{Research design}

The study mainly dealt with qualitative and data quantitative methods which were guided by the 5 point likert scale questionnaire on poverty and criminal to guide the respondents in giving their responses to the study questions of the research

The research used descriptive research on the influence of poverty on crime among the Abanyole in Emuhaya district through interview, observation from the study area. These helped to asses the relevancy and crime problems facing the population in the stud area. The qualitative dealt with halation of facts from the questionnaires filled by the respondents while the quantitative presented the statistical data derived from the questionnaire on poverty and crime within the study area. Descriptive method can broadly be classified as primary as quantitative or qualitative. (Cozby 1981:78) Qualitative description of finding focused on the themes 
that emerged from discussed, likert questionnaire and the way the respondents conceptualized the issue and is expressed in xion- numerical term using the language and images

The research made naturalistic observation in air, road, schools, markets, areas, villages over an extended period of tie through random sampling, interview then the observation, were interpreted and recorded in note book. Naturalistic observation demands that the researcher immerse themselves in situation in the field of research and observe everything, the setting pattern of personal relationship and people's reaction to events. The goal was to provide a complete and accurate picture rather than to test hypotheses formed prior to the study. The researcher must keep detailed notes (Cosby 1981:79). Naturalistic observation is undertaken when a researcher wants to describe and understand how people in a social or cultural setting live, work and experience the setting. Naturalistic observation method involves observing people (informants) to provide inside information, talking to people about their lives, examining their documents produced in the setting such as memory, news papers, news letters.[63]

Amin (2005) show quantitative data employs extensive and intensive observations, interviews and discussions, thus seeks to derive and describe findings that promote greater understanding of how and why people behave the way they do. Quantitative research involves the collection of numerical data in order to explain, predict and control the phenomena of interest, data analysis being mainly statistical involve collecting data to test hypothesis or to answer questions concerning the current status of the subject of study. Quantitative researchers attempt to control as many variables as possible and prefer strategies like random sampling, random assignment, to treatment groups, use standard instruments and when appropriate and equalizing of conditions of groups to be compared. Quantitative researchers are more concerned with generation of findings than the meaning of those findings, they-feasible using probabilistic sampling techniques.[70]

\subsection{Research population}

The research covered Emuhaya District with the area of $173.2 \mathrm{~km} 2$ and populations of 240,000 with a population density of 1114 persons per $\mathrm{km} 2$.There are 8 locations and several sub-locations as administrative units in the region. The common dialect of the people is Luhya. The study encompassed the provincial administration from the 4 locations and chiefs from the sampled sub-locations level. Data collections will also enhanced from the Children's Department, markets, Education, Office Magistrate Maseno Police Stations, Commercial Banks Women groups, and Civil Population, Youth Groups, Shopkeepers and Women Groups. Survey sampling will be used to provide relevant information on influence of poverty to help make resolutions and recommendations.[41]

\subsubsection{Sample size and sampling procedure}

The study sample will be 124(male 90 and female 34) respondents who will be sampled using nonprobability sampling of the population to give everyone an equal chance as a respondent. The data collected will be generalized. Haphazard sampling techniques will be applied within the district and respondents interviewed on variables of poverty and crime. Survey design will be applied on selected sub groups to study the relationship between two variables of crime and poverty and their impact on the lives of the Abanyole of Emuhaya with an area of $173.2 \mathrm{~km}^{2}$. Sampling with the help of a sampling frame will be employed for data collection.

Sampling frame is the actual list or some sampling unit from which he sample or some stage of the sample is selected (Babbie 1995:194). The chiefs, police, children department, criminals and magistrate courts will give responses on the legal framework crime in the area. The hospitals, human rights, departments, education officers, teachers, women will give findings on crime while the market officials, civilians, banks, farmers, women groups, NGO's, CDF, Co-operative officials and old age will give information on poverty and crime in the area of the study.[73]

Sampling frame of the study population

\begin{tabular}{|l|l|l|l|}
\hline Respondent & Emuhaya Division & Luanda Division & Total \\
\hline Chiefs & $\mathbf{4}$ & $\mathbf{4}$ & $\mathbf{8}$ \\
\hline Police & $\mathbf{6}$ & $\mathbf{6}$ & $\mathbf{1 2}$ \\
\hline Human right department & $\mathbf{2}$ & $\mathbf{2}$ & $\mathbf{4}$ \\
\hline Youth groups & $\mathbf{2}$ & $\mathbf{2}$ & $\mathbf{4}$ \\
\hline Women groups & $\mathbf{2}$ & $\mathbf{2}$ & $\mathbf{4}$ \\
\hline Farmer & $\mathbf{1 0}$ & $\mathbf{1 0}$ & $\mathbf{2 0}$ \\
\hline Education office & $\mathbf{2}$ & $\mathbf{2}$ & $\mathbf{4}$ \\
\hline Market/Businessmen & $\mathbf{5}$ & $\mathbf{5}$ & $\mathbf{1 0}$ \\
\hline Financial institutions & $\mathbf{4}$ & $\mathbf{4}$ \\
\hline Hospitals & $\mathbf{2}$ & $\mathbf{2}$ & $\mathbf{4}$ \\
\hline Co-operatives & $\mathbf{2}$ & $\mathbf{2}$ & $\mathbf{4}$ \\
\hline Former criminals & $\mathbf{3}$ & $\mathbf{3}$ & $\mathbf{6}$ \\
\hline
\end{tabular}


The Influence of Poverty on Crime Among The Abanyole of Emuhaya District, Western Kenya

\begin{tabular}{|l|l|l|l|}
\hline The Old Age & $\mathbf{2}$ & $\mathbf{2}$ & $\mathbf{4}$ \\
\hline Constituency Offices (CDF) & & $\mathbf{1}$ & $\mathbf{1}$ \\
\hline Church/Clergy & $\mathbf{1}$ & $\mathbf{1}$ & $\mathbf{2}$ \\
\hline Employed groups & $\mathbf{1 2}$ & $\mathbf{1 2}$ & $\mathbf{2 4}$ \\
\hline Un-employed groups & $\mathbf{5}$ & $\mathbf{5}$ & $\mathbf{1 0}$ \\
\hline Total & $\mathbf{6 2}$ & $\mathbf{6 2}$ & $\mathbf{1 2 4}$ \\
\hline
\end{tabular}

\subsubsection{Research instruments}

There two main sources of data mainly primary and secondary data. The secondary data was constituted from the resource books, references books, court files for court cases, journals, newspapers, magazines, and financial records from community development fund in the Emuhaya, market data from market and business communicates transactions. The secondary data helped in relating and the primary data to create a gap in knowledge and make recommendations and conclusions on poverty and crime among the Abanyole in Emuhaya District in Western Kenya. The primary data combined open-ended questionnaires on poverty and crime. The instruments consist of a questionnaire between poverty and crime (QPRBPC).

The questionnaire has two major sections A and B. Section A is on biographical information of respondents. Section B has six sub-sections on the influence of poverty on financial standing with six items, employment with five items, family structure with five items, social support with five items and property with six items on crime.

The questionnaire adopted a five item likert scale ranging from strongly agree equal to 5 , strongly disagree equals to 1 . The Cronbach's alpha (Internal Consistency Reliability) for the total questionnaire items while the Cronbach's alpha for each section is as follows: Financial Standing $\alpha=.5885$, family structure alpha $\alpha$ $=.5982$, social support $\alpha=.7496$, Level of Education $\alpha=.3742$, Employment $\alpha=.3683$, Property alpha $\alpha=$ .6162 .

This is pre-tested by 10 respondents in the study area to check for validity and reliability. The questionnaire on poverty and crime was administered to court officials, police officers, chief, assistant chiefs, clergy, focus group from the study population verify the information on the influence of poverty on crime questionnaire. The closed ended were effective in issuing quick and efficient information on the problem. The interviews and observations randomly sampled got valid information from respondents on face to face interactions to beat up the data on poverty and crime in the study area. Most of the residents are poor with low financial standing, low social support, property, low level of education and unemployment leading to poverty and crime within the study area.

\subsubsection{Validity and reliability}

The likert scale closed-ended questionnaire was validated using a chi-square to come up with statistical data and test for validity and reliability through the Cronbach's alpha and Internal Consistency and Reliability before it was administered to 124 respondents for data correction.

\subsubsection{Data gathering procedure}

The research used both primary and secondary data collection methods. The primary data was collected by the 5 item Likert Scale ranging from strongly agree to strongly disagree, random sampling, observation and interviews were used to collect data to back up questionnaire data. 124 questionnaires were administered in all the locations on the sampled population size. Most of the respondents who were given questionnaires to collect data on property and crime were designed in accordance to the objectives and hypothesis of the study. The direct administration of the questionnaires yielded $100 \%$ collection back for data analysis. Secondary data on the literature review was gathered from library resource, reference books, newspapers, departments, records from urban centres, hospitals, court, CDF (Constituency Development Fund) offices, journals, in notebooks, trade publications, school, children rights offices, education offices, District Commissioners Office and Internet, this information was recorded in notebook.

\subsubsection{Data analysis}

The primary data of 124 respondents was analyzed using Statistical Package for Social Sciences (SPSS) to get results for quantitative data on financial standing, employment, family structure, social support level of education and property variables of the research likert scale questionnaire ranging from $\mathrm{SA}=5$ to $\mathrm{SD}=1$. The chi-square $\mathrm{X}^{2}$ test was used to analyze the statistical data and then put in tables of responses.

Cronbach's Alpha was used to test for literal validity and reliability of the data. The secondary data was qualitatively synthesized and documented together with results from the primary data for literature review, discussions, conclusion and recommendation of the study. 


\subsection{Ethical consideration}

Due to the nature of the study being undertaken, the study adhered to professional research ethics, legal frameworks and confidentiality to avoid unnecessary misunderstandings, conflict and ethical dilemmas. The study protected the participants in the area, earlier arrangements and confidentiality was paramount. Classification of obligations and responsibilities was confined to the researcher. Research laws and regulations were adhered to all levels before and after the publications of this research.

\section{4 Limitation on the study}

The study was limited in Emuhaya District of Western Kenya. The data collection was entirely on 124 people and was mainly focused on poverty and crime. There was scarcity of resources, superstitions, misconception, lack of adequate funds and some respondents could not submit the relevant information on crime, poverty and human rights violation in Emuhaya District.

\subsection{Introduction}

\section{Data Analysis And Presentation}

The chapter deals with data analysis on relationship between poverty on financial standing, employment, family structure, social support, level of education and property on crime within the study area. The results of the table 1 to 6 have been analysis using $X^{2}$ calculations in which $X^{2}$ tables is 7.79 where the level of significance is 0.05 and the degree of freedom is $(\mathrm{DF})=4$ to show the tendencies to commit crime.

4.1 Table 1. Relationship between financial standing and crime

\begin{tabular}{|c|c|c|c|c|c|c|c|c|c|}
\hline LEVEL OF RESPONSES & & SA & $\mathrm{A}$ & $\mathrm{N}$ & $\mathrm{O}$ & SA & $\mathrm{X}^{2}$ cal & $\mathrm{X}^{2}$ table & $\mathrm{P}$ \\
\hline $\begin{array}{l}\text { When people with low financial standing steal } \\
\text { other people's property }\end{array}$ & $\begin{array}{l}\text { Observed } \\
\text { expected }\end{array}$ & $\begin{array}{l}39 \\
24.8 \\
\end{array}$ & $\begin{array}{l}62 \\
24.8 \\
\end{array}$ & $\begin{array}{l}15 \\
24.8 \\
\end{array}$ & $\begin{array}{l}6 \\
24.8 \\
\end{array}$ & $\begin{array}{l}2 \\
24.8 \\
\end{array}$ & $\begin{array}{l}103.02 \\
24.8 \\
\end{array}$ & \multirow{6}{*}{7.79} & \multirow{6}{*}{0.05} \\
\hline $\begin{array}{l}\text { Rich people are Not likely to steal other } \\
\text { people's property }\end{array}$ & $\begin{array}{r}\text { Observed } \\
\text { expected }\end{array}$ & $\begin{array}{l}8 \\
24.8 \\
\end{array}$ & $\begin{array}{l}30 \\
24.8 \\
\end{array}$ & $\begin{array}{l}14 \\
24.8\end{array}$ & $\begin{array}{l}52 \\
24.8 \\
\end{array}$ & $\begin{array}{l}20 \\
24.8\end{array}$ & 47.94 & & \\
\hline $\begin{array}{l}\text { Low income earners engage in criminal offences } \\
\text { in the community }\end{array}$ & $\begin{array}{r}\text { Observed } \\
\text { expected }\end{array}$ & $\begin{array}{l}31 \\
24.0\end{array}$ & $\begin{array}{l}54 \\
24.0\end{array}$ & $\begin{array}{l}13 \\
24.0\end{array}$ & $\begin{array}{l}19 \\
24.0\end{array}$ & $\begin{array}{l}3 \\
24.0\end{array}$ & 64.00 & & \\
\hline $\begin{array}{l}\text { Investments owned by the rich , in the } \\
\text { community are illegally acquired }\end{array}$ & $\begin{array}{r}\text { Observed } \\
\text { expected }\end{array}$ & $\begin{array}{l}12 \\
24.6\end{array}$ & $\begin{array}{l}41 \\
24.6\end{array}$ & $\begin{array}{l}23 \\
24.6\end{array}$ & $\begin{array}{l}39 \\
24.6\end{array}$ & $\begin{array}{l}8 \\
24.6\end{array}$ & 37.12 & & \\
\hline $\begin{array}{l}\text { Youths from poor families result to crime to } \\
\text { earn their daily bread }\end{array}$ & $\begin{array}{r}\text { Observed } \\
\text { expected }\end{array}$ & $\begin{array}{l}22 \\
24.6\end{array}$ & $\begin{array}{l}46 \\
24.6\end{array}$ & $\begin{array}{l}30 \\
24.6\end{array}$ & $\begin{array}{l}17 \\
24.6\end{array}$ & $\begin{array}{l}8 \\
24.6\end{array}$ & 33.63 & & \\
\hline $\begin{array}{l}\text { Poor people commit criminal activities by } \\
\text { engaging in selling of drugs in your community }\end{array}$ & $\begin{array}{r}\text { Observed } \\
\text { expected }\end{array}$ & $\begin{array}{l}29 \\
24.6\end{array}$ & $\begin{array}{l}41 \\
24.6\end{array}$ & $\begin{array}{l}19 \\
24.6\end{array}$ & $\begin{array}{l}26 \\
24.6\end{array}$ & $\begin{array}{l}8 \\
24.6\end{array}$ & 24.28 & & \\
\hline
\end{tabular}

Observed SA- strong Agree

Expected A-agree

$\mathrm{N}$ - Neutral

D - Disagree

$\mathrm{SD}$ - Strong Disagree

$\mathrm{P}-$ level of significance

$\mathrm{X}^{2} \mathrm{cal}$ - chi square calculations

$\mathrm{X}^{2}$ table - chi square table of significance

The results on the table 1 show the chi - square analysis of the relationship between financial standing and the tendency to commit crime. The result indicate that there was significance relationship between financial standards of people and the tendency to commit crime $\left(\mathrm{X}^{2}=305.99, \mathrm{DF}=4 \mathrm{p}<.05\right)$ the result reveal that the chi square calculated value of 308.99 is higher than the chi - square table value of 77.9 at $\mathrm{P}<.05$. Therefore the null hypothesis is rejected. These means that the poor the financial standing of the people the higher their tendency to commit crime.

This result shows that when people have low financial standing they have the tendency to commit crime such as engaging in drug abuse, murder, stealing, embezzlement , white collar crimes ,burglary, shoplifting, prostitution and other finance related criminal activities. 


\subsection{Table 2. Relationship between employment and crime}

\begin{tabular}{|c|c|c|c|c|c|c|c|c|c|}
\hline LEVEL OF RESPONSES & & SA & A & $\mathrm{N}$ & $\mathrm{O}$ & SA & $\mathrm{X}^{2} \mathrm{cal}$ & $\begin{array}{l}\mathrm{X}^{2} \text { ta } \\
\text { ble }\end{array}$ & $\mathrm{P}$ \\
\hline $\begin{array}{l}\text { People engage in crime to nurse their } \\
\text { frustration }\end{array}$ & $\begin{array}{l}\text { Observed } \\
\text { Expected }\end{array}$ & $\begin{array}{l}15 \\
24.6\end{array}$ & $\begin{array}{l}62 \\
24.6 \\
\end{array}$ & $\begin{array}{l}22 \\
24.6\end{array}$ & $\begin{array}{l}21 \\
24.6\end{array}$ & $\begin{array}{ll}3 \\
24.6\end{array}$ & 80.37 & \multirow{5}{*}{7.79} & \multirow{5}{*}{.05} \\
\hline $\begin{array}{l}\text { Your community do not engage in } \\
\text { criminal activities }\end{array}$ & $\begin{array}{l}\text { Observed } \\
\text { Expected }\end{array}$ & $\begin{array}{l}10 \\
24.4 \\
\end{array}$ & $\begin{array}{l}17 \\
24.4 \\
\end{array}$ & $\begin{array}{l}29 \\
24.4 \\
\end{array}$ & $\begin{array}{l}48 \\
24.4 \\
\end{array}$ & $\begin{array}{l}18 \\
24.4 \\
\end{array}$ & 36.12 & & \\
\hline $\begin{array}{l}\text { Farmers, casual workers, unemployed } \\
\text { likely engage in criminal activities }\end{array}$ & $\begin{array}{l}\text { Observed } \\
\text { Expected }\end{array}$ & $\begin{array}{l}12 \\
24.6 \\
\end{array}$ & $\begin{array}{l}39 \\
24.6 \\
\end{array}$ & $\begin{array}{l}24 \\
24.6 \\
\end{array}$ & $\begin{array}{l}32 \\
24.6 \\
\end{array}$ & $\begin{array}{l}16 \\
24.6 \\
\end{array}$ & 2.13 & & \\
\hline $\begin{array}{l}\text { Unemployed youths have the propensity } \\
\text { to engage in criminal activities }\end{array}$ & $\begin{array}{l}\text { Observed } \\
\text { Expected }\end{array}$ & 24.4 & 24.4 & 24.4 & 24.4 & 24.4 & & & \\
\hline $\begin{array}{l}\text { Employment in y community is through } \\
\text { criminal means }\end{array}$ & $\begin{array}{l}\text { Observed } \\
\text { Expected }\end{array}$ & $\begin{array}{l}27 \\
24.4 \\
\end{array}$ & $\begin{array}{l}44 \\
24.4 \\
\end{array}$ & $\begin{array}{l}18 \\
24.4 \\
\end{array}$ & $\begin{array}{l}24 \\
24.4 \\
\end{array}$ & $\begin{array}{l}9 \\
24.4 \\
\end{array}$ & 27.43 & & \\
\hline
\end{tabular}

Observed

SA- strong Agree

Expected

A-agree

$\mathrm{N}$ - Neutral

D - Disagree

SD - Strong Disagree

$\mathrm{P}$-level of significance

$\mathrm{X}^{2}$ cal - chi square calculations

$\mathrm{X}^{2}$ table - chi square table of significance

Table 6

The results on table 2 show the chi - square analysis of the relationship between employment and the tendency to commit crime. The results indicate that there was significant relation between the employment level of the people and their tendency to commit crime $\left(\mathrm{X}^{2}=265.56 \mathrm{DF}=4 \mathrm{P}<0.05\right.$. $)$ The results reveal that the Chisquare calculated value of 265.56 is higher than the Chi-square table value of 7.79 at $\mathrm{P}<0.05$. Therefore the null hypothesis is rejected. This results show that when people are unemployed they have a tendency to commit criminal activities like stealing, drug abuse, burglary, larceny corruption ,gross violation of human rights, selling illicit drinks such as chang'aa and busaa, bribery and others.

\subsection{Table 3. Relationship between family structure and crime}

\begin{tabular}{|c|c|c|c|c|c|c|c|c|c|}
\hline LEVEL OF RESPONNSES & & SA & $\mathrm{A}$ & $\mathrm{N}$ & $\mathrm{O}$ & SA & $\mathrm{X}^{2} \mathrm{cal}$ & $\begin{array}{l}\mathrm{X}^{2} \mathrm{tab} \\
\text { le }\end{array}$ & $\mathrm{P}$ \\
\hline $\begin{array}{l}\text { Rich households don't involve } \\
\text { selling illegal substances leading } \\
\text { to criminal offences }\end{array}$ & $\begin{array}{l}\text { Observed } \\
\text { Expected }\end{array}$ & $\begin{array}{l}27 \\
24.6\end{array}$ & $\begin{array}{l}40 \\
24.6\end{array}$ & $\begin{array}{l}12 \\
24.6\end{array}$ & $\begin{array}{l}31 \\
24.6\end{array}$ & $\begin{array}{l}18 \\
24.6\end{array}$ & 19.81 & \multirow{5}{*}{7.79} & \multirow{5}{*}{0.05} \\
\hline $\begin{array}{l}\text { Extended homes are prone basic } \\
\text { needs leading to criminal } \\
\text { activities }\end{array}$ & $\begin{array}{l}\text { Observed } \\
\text { Expected }\end{array}$ & $\begin{array}{l}30 \\
24.4\end{array}$ & $\begin{array}{l}51 \\
24.4\end{array}$ & $\begin{array}{l}21 \\
24.4\end{array}$ & $\begin{array}{l}15 \\
24.4\end{array}$ & $\begin{array}{l}5 \\
24.4\end{array}$ & 49.80 & & \\
\hline $\begin{array}{l}\text { Domestic strife is experienced } \\
\text { criminal activities in my areas }\end{array}$ & $\begin{array}{l}\text { Observed } \\
\text { Expected }\end{array}$ & $\begin{array}{l}16 \\
24.6\end{array}$ & $\begin{array}{l}52 \\
24.6\end{array}$ & $\begin{array}{l}22 \\
24.6\end{array}$ & $\begin{array}{l}27 \\
24.6\end{array}$ & $\begin{array}{l}6 \\
24.6\end{array}$ & 48.10 & & \\
\hline $\begin{array}{l}\text { Children headed engage in } \\
\text { criminal activities }\end{array}$ & $\begin{array}{l}\text { Observed } \\
\text { Expected }\end{array}$ & $\begin{array}{l}33 \\
24.6\end{array}$ & $\begin{array}{l}47 \\
24.6\end{array}$ & $\begin{array}{l}25 \\
24.6\end{array}$ & 24.6 & $\begin{array}{l}5 \\
24.6\end{array}$ & 44.36 & & \\
\hline $\begin{array}{l}\text { Families where husbands do not } \\
\text { provide basic needs are involved } \\
\text { in crime }\end{array}$ & $\begin{array}{l}\text { Observed } \\
\text { Expected }\end{array}$ & $\begin{array}{l}20 \\
24.4\end{array}$ & $\begin{array}{l}57 \\
24.4\end{array}$ & $\begin{array}{l}17 \\
24.4\end{array}$ & $\begin{array}{l}24 \\
24.4\end{array}$ & $\begin{array}{l}4 \\
24.4\end{array}$ & 63.66 & & \\
\hline \multicolumn{7}{|l|}{ Total $X^{2}=$} & \multicolumn{3}{|l|}{225.73} \\
\hline
\end{tabular}

Observed SA- strong Agree

Expected A-agree

N - Neutral

D - Disagree

SD - Strong Disagree

$\mathrm{P}-$ level of significance

$\mathrm{X}^{2}$ cal - chi square calculations

$\mathrm{X}^{2}$ table - chi square table of significance

Table 3; Show the chi - square analysis of the relationship between family structure and the tendency to commit crime. The result indicates that there is significant relationship between the family structure and the tendency of the people to commit crime $\left(\mathrm{X}^{2} 225.73 \mathrm{DF}=4, \mathrm{P}<0.05\right)$. The results reveal that the chi - square calculated value of 225.73 is higher than the chi - square table values of 7.79 at $\mathrm{P}<0.05$ 'therefore the null 
hypothesis is rejected. This means that the family structure of the people contributes to their tendency to commit crime. The analysis shows that when people don't have proper family structures one is liable to commit crime such as gender based violence, prostitution, destitute, juvenile delinquency, drug abuse, and selling, low education and many other

4.4 Table 4. Relationship between social support and crime

\begin{tabular}{|c|c|c|c|c|c|c|c|c|c|}
\hline LEVEL OF RESPONSES & & SA & A & $\mathrm{N}$ & $\mathrm{O}$ & SA & $\mathrm{X}^{2} \mathrm{cal}$ & $\mathrm{X}^{2}$ table & $P$ \\
\hline $\begin{array}{l}\text { Most criminal with rich relatives are } \\
\text { hardly tried before the law }\end{array}$ & $\begin{array}{l}\text { Observed } \\
\text { Expected }\end{array}$ & $\begin{array}{l}51 \\
24.6\end{array}$ & $\begin{array}{l}50 \\
24.6\end{array}$ & $\begin{array}{l}5 \\
24.6\end{array}$ & $\begin{array}{l}11 \\
24.6\end{array}$ & $\begin{array}{l}6 \\
24.6\end{array}$ & 91.76 & \multirow{5}{*}{7.79} & \multirow{5}{*}{0.05} \\
\hline $\begin{array}{l}\text { NGOs in your community support } \\
\text { youths to get education and daily basic } \\
\text { needs to avoid crime }\end{array}$ & $\begin{array}{l}\text { Observed } \\
\text { Expected }\end{array}$ & $\begin{array}{ll}16 \\
24.8\end{array}$ & $\begin{array}{l}43 \\
24.8\end{array}$ & $\begin{array}{l}18 \\
24.8\end{array}$ & $\begin{array}{ll}26 \\
24.8\end{array}$ & $\begin{array}{ll}11 \\
24.8\end{array}$ & 18.98 & & \\
\hline $\begin{array}{l}\text { Youth without family support engage in } \\
\text { criminal activities }\end{array}$ & $\begin{array}{l}\text { Observed } \\
\text { Expected }\end{array}$ & $\begin{array}{ll}33 \\
20.7\end{array}$ & $\begin{array}{ll}64 \\
20.7 \\
\end{array}$ & $\begin{array}{ll}12 \\
20.7\end{array}$ & $\begin{array}{ll}11 \\
20.7\end{array}$ & $\begin{array}{ll}3 \\
20.7 \\
\end{array}$ & 140.19 & & \\
\hline $\begin{array}{l}\text { Vulnerable people get financial and } \\
\text { material support from their next of kin } \\
\text { and well wishers as such hardly engage } \\
\text { in criminal activities }\end{array}$ & $\begin{array}{l}\text { Observed } \\
\text { Expected }\end{array}$ & $\begin{array}{l}9 \\
24.6\end{array}$ & $\begin{array}{c}14 \\
24.6\end{array}$ & $\begin{array}{l}29 \\
24.6\end{array}$ & $\begin{array}{l}49 \\
24.6\end{array}$ & $\begin{array}{l}22 \\
24.6\end{array}$ & 39.72 & & \\
\hline $\begin{array}{l}\text { The constituency development fund } \\
\text { (CDF) support the vulnerable to reduce } \\
\text { hunger and crime }\end{array}$ & $\begin{array}{l}\text { Observed } \\
\text { Expected }\end{array}$ & $\begin{array}{c}10 \\
24.8\end{array}$ & $\begin{array}{ll}23 \\
24.8\end{array}$ & $\begin{array}{l}18 \\
24.8\end{array}$ & $\begin{array}{l}41 \\
24.8\end{array}$ & $\begin{array}{ll}32 \\
24.8\end{array}$ & 23.50 & & \\
\hline
\end{tabular}

Observed

Expected

SA- strong Agree

$\mathrm{N}$ - Neutral

A-agree

D - Disagree

$\mathrm{SD}$ - Strong Disagree

$\mathrm{P}-$ level of significance

$\mathrm{X}^{2} \mathrm{cal}$ - chi square calculations

$\mathrm{X}^{2}$ table - chi square table of significance

Table 4; show the chi - square analysis of the relationship between family social support and the tendency to commit crime. The results indicate that there is significance relation between family social support and the tendency to commit crime. $\left(\mathrm{X}^{2}=314.15, \mathrm{df}=4 \mathrm{P}<0.05\right)$ The result reveal that the chi-square table value of 7.79 at $\mathrm{P}<0.05$. Therefore the null hypothesis is rejected. This result show that lack of social support contributes to people's tendency to commit crime The result of the analysis show that when people have instable or lack of social support they have a tendency to commit crime such as gender based violence, divorce, separation, abandonment of children, street children, murder, stealing, selling drugs, substances abuse and others.

\subsection{Table5: Relationship between level of education and crime}

\begin{tabular}{|c|c|c|c|c|c|c|c|c|c|}
\hline LEVEL OF RESPONSES & & SA & $\mathrm{A}$ & $\mathrm{N}$ & $\mathrm{O}$ & SA & $\mathrm{X}^{2} \mathrm{cal}$ & $\mathrm{X}^{2}$ table & $\mathrm{P}$ \\
\hline $\begin{array}{l}\text { Families headed by educated parents } \\
\text { don't engage in criminal offences }\end{array}$ & $\begin{array}{r}\text { Observed } \\
\text { expected }\end{array}$ & $\begin{array}{ll}17 \\
24.8\end{array}$ & $\begin{array}{ll}35 \\
24.8\end{array}$ & $\begin{array}{ll}16 \\
24.8\end{array}$ & $\begin{array}{ll}45 \\
24.8 \\
\end{array}$ & $\begin{array}{ll}1 \\
24.8\end{array}$ & 33.90 & \multirow{5}{*}{7.79} & \multirow{5}{*}{0.05} \\
\hline $\begin{array}{l}\text { Low education contributes low } \\
\text { income and unemployment leading } \\
\text { to crime }\end{array}$ & $\begin{array}{l}\text { Observed } \\
\text { expected }\end{array}$ & $\begin{array}{l}41 \\
24.8\end{array}$ & $\begin{array}{l}51 \\
24.8\end{array}$ & $\begin{array}{l}10 \\
24.8\end{array}$ & $\begin{array}{l}18 \\
24.8\end{array}$ & $\begin{array}{l}4 \\
24.8\end{array}$ & 66.40 & & \\
\hline $\begin{array}{l}\text { Good education reduces criminal } \\
\text { activities in the community }\end{array}$ & $\begin{array}{r}\text { Observed } \\
\text { expected }\end{array}$ & $\begin{array}{c}30 \\
24.8 \\
\end{array}$ & $\begin{array}{ll}58 \\
24.8 \\
\end{array}$ & $\begin{array}{ll}20 \\
24.8\end{array}$ & $\begin{array}{l}10 \\
24.8 \\
\end{array}$ & $\begin{array}{ll}6 \\
24.8 \\
\end{array}$ & 60.55 & & \\
\hline $\begin{array}{l}\text { The level of education has no impact } \\
\text { on development and crime among } \\
\text { the households }\end{array}$ & $\begin{array}{l}\text { Observed } \\
\text { expected }\end{array}$ & $\begin{array}{l}6 \\
24.8\end{array}$ & $\begin{array}{l}32 \\
24.8\end{array}$ & $\begin{array}{l}21 \\
24.8\end{array}$ & $\begin{array}{l}49 \\
24.8\end{array}$ & $\begin{array}{l}16 \\
24.8\end{array}$ & 43.66 & & \\
\hline $\begin{array}{l}\text { Highly educated, skilled community } \\
\text { members hardly engage in criminal } \\
\text { activities }\end{array}$ & $\begin{array}{l}\text { Observed } \\
\text { expected }\end{array}$ & $\begin{array}{l}31 \\
24.4\end{array}$ & $\begin{array}{l}44 \\
24.4\end{array}$ & $\begin{array}{l}17 \\
24.4\end{array}$ & $\begin{array}{l}49 \\
24.4\end{array}$ & $\begin{array}{l}19 \\
24.4\end{array}$ & 28.33 & & \\
\hline
\end{tabular}

Observed

Expected SA- strong Agree

$\mathrm{N}$ - Neutral

A-agree

D - Disagree

SD - Strong Disagree

$\mathrm{P}$-level of significance 
$\mathrm{X}^{2}$ cal - chi square calculations

$\mathrm{X}^{2}$ table - chi square table of significance

Table 5: show the chi - square analysis of the level of education and the tendency to commit crime. The result indicate that there was significant relationship between the level of education of the people and tendency to commit crime $\left(\mathrm{X}^{2}=241.84, \mathrm{df}=4, \mathrm{P}<0.05\right)$. The result reveal that the chi - square calculated value of 241.84 is higher than the chi - square value of 7.79 at $\mathrm{P}<0.05$. Therefore the null hypothesis is rejected. The result shows that when people have low level of education they have tendency to commit crime as gender based violence, discrimination, stealing, and juvenile delinquencies.

4.6. Table 6. Relationship between property and crime

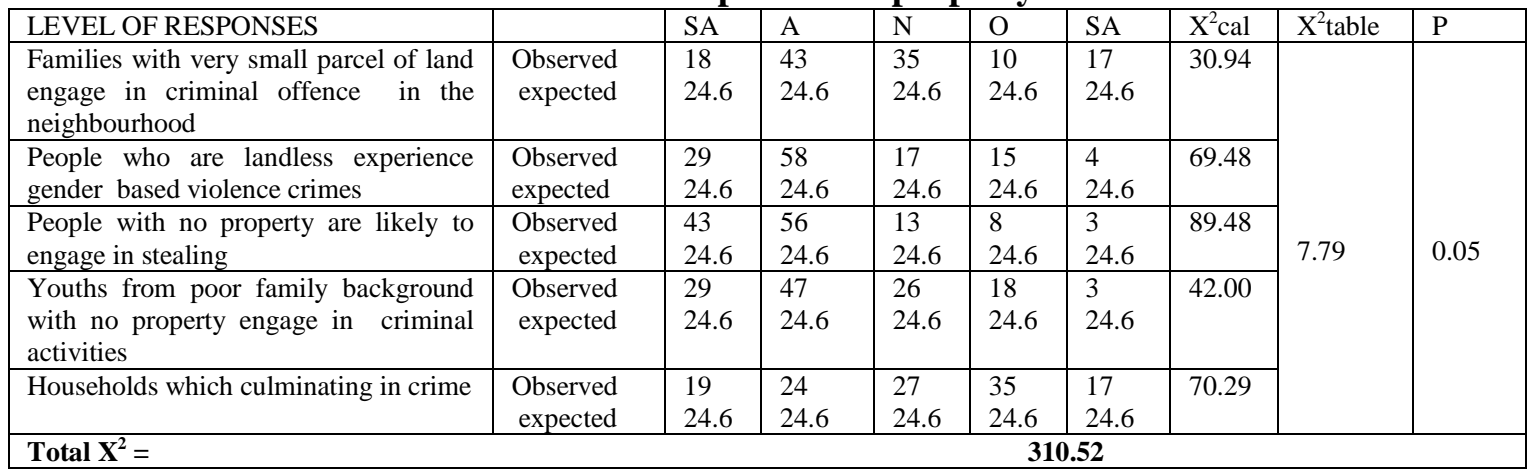

Observed

Expected

SA- strong Agree

$\mathrm{N}$ - Neutral

A-agree

$\mathrm{D}$ - Disagree

$\mathrm{SD}$ - Strong Disagree

$\mathrm{P}$-level of significance

$\mathrm{X}^{2}$ cal - chi square calculations

$\mathrm{X}^{2}$ table - chi square table of significance

Table 6 The results of table 6 show the chi - square analysis of the relationship between property and the tendency to commit crime. The result indicate that there is significant relationship between the level of the property ownership and the tendency to commit crime $\left(X^{2}=310.52\right.$, $\left.\mathrm{df}=4, \mathrm{P}<0.05\right)$ The result reveal that the chi- square calculated value of 310.52 is higher than the chi - square table value of 7.79 at $\mathrm{P}<0.05$. Therefore the null hypothesis is rejected. This means that the low property ownership by the people contributes to the tendency to commit crime. This result shows that when people have low or no possession of property they have tendency to commit crime .this results shows that when people have low or no property they have a tendency to commit crime such as gender based violence of human rights, gender - based violence, discrimination, stealing, juvenile delinquencies, and other offences.

\subsection{Introduction}

\section{Discussion}

The chapter covers the findings of the relationship between financial standing, employment, family structure, social support, level of education, property on crime in the study area

\subsection{Findings of the relationship between financial standing and crime}

It was hypothesized that there was no relationship between financial standing and crime among the Abanyole people of Emuhaya District Western Kenya.

Findings from testing $\mathrm{H} 1$ revealed that there was significant relationship between financial standing of the people and the tendency to commit crime. Result from this work support the work of Eshleman (2003) who found that criminal activities and crime rates vary in different legal jurisdictions which accompany different rates of enforcement. On financial crimes professionals and respectable people who through corruption, embezzle, siphoned off billions of dollars of peoples money for personal use, lawyers defrauding their clients, white collar crime which included consumer fraud, price fixing, stock manipulation, inside trading, income tax evasion, misrepresentation in advertising and bribery. His research shows that organized crime consisted groups 
carrying out illegal activities of drug distribution, operation of large scale illegal business which accrues a lot of money.[32]

The study is also supported by Mauri (2004) who reported that household savings are part of the spending unit income which is not consumed especially those spent of purchases of consumer durables as jewellery are treated as part of savings. But this contradicts the World bank (1986) statement on research findings that crisis in Sub Sahara Africa has now almost witnessed a decade of falling per capita income accelerating ecology degradation, per capita food production has failed since 1980 and the trend continues in the poorest Africa Countries World Bank (1989) report show that the growth of Africa investment stopped in the 1970s including the drop in both domestic and foreign savings terms of trade and production declined reducing real income and a large public sector deficit between 1984-85 worsening domestic economic performance leading to high poverty index in Africa and Kenyan households. Laver and Robert Laver (2002) show that female and single parents have in recent years joined low wage employment to generate income to purchase some basic household needs to alleviate hunger and starvation. [62]

Parrillo (2002) supports Jearette and Laurer (2002) that even women in the past who often depended on men for financial support have even terminated miserable marriages and have become self reliance through employment (self supporting) at the same time. Another research shows divorce has long term $\mathrm{m}$ and short term implications on mental and physical well being of the household, men and women face depression and result to murder, alcoholism, drug abuse, suicide and other continuous conflicts.

However the result from this study show the work of Eshleman et al (2003) that legal systems know some crimes committed by men and women due to low financial standing such as white collar crimes which are committees in the course of occupations on daily basis by the professionals and respectable people through embezzlement of public finds, bribes, siphoning of billions of dollars of other people's money, others are fraud, evasion of Tax, stock emancipations, inside trading criminal offences. [17]

An explanation for the findings from this study could be that low financial standing among the people in the study area lead to tendency to commit crime such as domestic violence, divorce and separation, murder, suicide among the household heads. The youth with low financial standing have resulted to find their survival through criminal means of stealing, burglary, robbery, with violence. Pick pocketing, gambling, commercial sex, drug abuse and selling illicit brews (chang'aa and busaa), street children and child labour. These activities are due to poverty as the study area lack income generating projects. Community Development Fund (CDF) has initiated a few projects for the youth and women on small holdings (micro economic activities). The region need revalidation on utilization of the available natural resources, food processing and industries, enterprises in the construction industry and strategic plans on new technologies and technical skills on arable farming, family homesteads re-allocated in areas with land to avert population pressure on the meagre resources.

\subsection{Findings of the relationship between employment and crime}

It was hypothesized that there was no relationship between the level of employment and crime among the Abanyole of Emuhaya District in Western Kenya.

Finding from testing $\mathrm{H}_{1}$ revealed that there was a significant relationship between levels of employment of the people and the tendency to commit crime in the study area. Results of this study support the work of Alexander and Laura (2004) who found out those employers were discriminating employees on gender, colour, race and religion so he advocated for a lawful employment practice for any employee and good terms of employment. He looked at Nepotism as the practice of hiring where some employers rely on to discriminate the job seekers as they use name, residence, educational background, ethnicity, marital status and the like. On gender discrimination some employers discriminate hiring married women, divorced, HIV/AIDs victims. There are also cases of sexual activity from job seekers in exchange for work.

Mulinge (2008) supports this findings by saying that children of separated, divorced or orphans end up doing petty jobs as housemaids, shamba boys, assist businessmen sell their products. This is a criminal offence to involve school going children into child labour with meagre wages. Most of the school dropouts and the non school going children are used by hawkers and businessmen in Luanda, Esibuye, and Kilingili markets to sell second hand clothing (mutumbaa), peddling alcohol, drugs and work in hotels where they are paid minimal wages. Some gangsters like the 42 brothers and Luanda Town down is composed of youths between $12-17$ years who organize theft and burglary among the households in the district. The income earners such as teachers and other civil servants live in fear with little government due to theft, murder, assault, burglary. Very many cases of murder has been reported this year 2010 to the civil leaders, politicians, police but the situation remains the same as the major issue of employment or alternative economic adventures have to be addressed to solve poverty and end crime in the study region.[19]

An explanation from this study could be poverty is the root cause of criminal activities in the study area since the households financial standing is quite low. There was unemployment amongst the youths and the household heads, low levels of investment; most families are landless, helpless and hopeless so they result to 
criminal activities like burglary, gambling, stealing, and price fixing, bribery amongst the civil servants fare hikes on commuter vehicle, corruption and embezzlement of government funds. Other financial related crime are high prices for purchase of food and also illicit drugs and substances abuse like chang'aa and busaa (local beer), tobacco, bhang, miraa sold in the rural communities and urban centres within the study area to generate income for the households. However from those findings the leadership of Emuhaya district should develop a strategic plan to solve unemployment by creating jobs to the youths, adults both female and males, improve on the land tenure systems, improve on wages of casual works like watchmen, house keeper, shamba boys women through investments funding, and microfinance business both in rural and urban centres in the study area.

\subsection{Findings of the relationship between family structure and crime}

It was hypothesized that there was no relationship between the family structure and the tendency to commit crime among the Abanyole in Emuhaya district the study area.

The findings from the testing of the $\mathrm{H}_{1}$, reveals that there was significant relationship between family structure and the tendency to commit crime in the region. The results from this findings support the work of Parillo (2002) who showed that since the world war 1 and world war II societal trends, legal reforms and increased women at work place has contributed to higher roles of divorce and there is continuous domestic strife and gender based violence among the house holds, children are abused and brothers abused by each other. The research of Parillo was also backed up with a study conducted in America in 1996 on examining 7000 couples in the National Survey on family households and revealed that men and women continually engage in physical violence and marital violence due to poverty. Another research in 1998 on the National elder abuse report in United States showed that over 45000 elders aged between 60 years and over are abused or neglected by family members. Women aged 80 years are grossly abused especially those suffering from diseases like hearing impairment, dementia, communication problems, loss of sight and inconsistency. This means that there is a tendency of the people to commit crime and violation of human rights in the world on all levels of mankind. The study of Paul Amato and Brice Keith reveal that children from divorce parents hardly complete school and may engage in early marriages and practice divorce like their parents. The divorce engaged in criminal activities or deviance behaviour like accidents, alcoholism, suicides, drug abuse, anxiety, child abuse and juvenile delinquency is noted amongst the family structures in most cases. [17]

An explanation for the findings from the study could be that family households with low levels of in come are subjected to low standard of living where poverty index is too high subjecting the members to commit crime in the study area.

\subsection{Findings of the relationship between social support and crime}

It was hypothesized that there was no relationship between social support and crime among Abanyole of Emuhaya Western Kenya.

Findings from testing the $\mathrm{H}_{1}$ reveal that there was significant relationship between social support and the tendency to commit crime in the study area. The results from this support the work of Newman (2002) who shows how conflicts theory show how women have been abused in households as they do extra free work outside the main stream economy in which work is defined as something one is paid to do. The theory explains the human rights violation on issues of work remunerations as it points out that women or mothers do child care, transportation, errands, household cleanings, laundry, cooking, bill paying, grocery shopping yet her salary is below a full time work [18].

At the same time the woman has to forego the few hours of rest to satisfy the husbands sexual needs thus ends up frustrated both at home and her work place. However results from this study support the research work on gender roles in Kenya that house work continuous to be pronominally female as they take and employment task. This research reveals how gender roles are abused in Kenya and the study area. Indeed men have the traditional notion that the household duties are for women and failure to fulfil their obligations results domestic violation, murder, assaults, child abuse, spouse and child battering, divorce or separation of the families. An explanation for the findings from the study could be that poverty is the key propelling factors to the household crimes in the study area of Emuhaya District. Social support involves financial and material support to the vulnerable poor to the households to help them meet the socio-economic challenges.

In 2003 the Uganda National Strategy addressed the mitigation on factors of susceptibility of HIV/AIDS infections as well as minimizing the burden of the disease at individual community and at National level. The common people include Voluntary Counselling and Testing (VCT) policy which has tested over 70000 people and the OVC policy to target the poor vulnerable groups thus aiming to address the needs of an estimated 1.7 millions of orphans. This initiative helps to reduce the HIV/AIDS prevalence within households. In Kenya Pathfinders International has supported reproductive health and family planning and training to Kenya citizens since 1969. They have worked closely with over 60 non governmental agencies, public and private 
sector institutions to reach the poorest communities with reproductive health information including contraceptives, counselling materials and child era services, (http://www.pathfind.org).[24]

Over the past 30 years, poverty has been on the rise in Kenya. Poverty seems to be the paradox in a country that has the best development economy in Eastern Africa with sector and substantial foreign exchange earning from agricultural exports and tourism, yet Kenya is a low income country with per capita income averaging US dollars 360 and is ranked 148 among 177 countries in Unites Nations Development in times of life expectancy, educational attainment and standards of living. (Http//www.ml:file//Bourne 14/cuttttttt/Enabling the rural poor to overcome poverty in mht). To address the above problem IFAD has invested a total of US dollars 1115 million in loaning financial programme and three grant financed programmes supporting the government efforts to reduce the rural Poverty. Investments include 18 million under Belgium Survival Fund joint Programme (BSFJP) and also US dollars 11 million towards helping the needy programmes among the vulnerable in Kenya. [20]. World Bank agricultural projects try to establish why the poor people move and why they are poor. Most of the support projects and programmes are appropriate technologies, increasing small holder's livestock production, promotion of farms income generating activities for small holders and encouraging community participation Kenya women Finance Trust (KWFT) micro finance institution helps to improve the women household income through savings and credit. The institution supports over 40,000 women members throughout the country. It ha intensified its focus in rural areas among the poor households, remote and marginalized areas. Social support can also take a form of sharing domestic tasks in the households which has been a bused in relation to the gender roles.

Newman (2002) uses the conflict theory to show how women have been abused in households that they work for free outside the main stream economy in which work is defined as something one is paid to do.

Ironically however domestic work is actually unavailable to the entire economic system. If women were to be paid the minimum going rate then they could earn more than the working men. It is estimated that HIV prevalent among the young and middle aged Kenyans die of HIV/AIDs related diseases or causes leading to orphans and even the women headed households are left vulnerable to poverty. The burden of HIV/AIDS and malaria on Kenyan families affect their income, food security and development potential in the region. Life expectancy is down to 46 years from 59 in 1989. [18]

The Kenyan government put in place in 2002 signaled a major political change in Kenya as indicated in the Economy Recovery Strategy for Wealth Creation (KERSWC) which includes Kenya Poverty Reduction Paper (KPRP) (2001 -2004) to improve on governance and reduce corruption, provide promote better health services and education, promote structural reforms for liberalized economy and to achieve equitable distribution and conservation of the Natural resources and promote the private sector. These programmes are subjected to support the poor house holds lift up from poverty to a life sustaining programme.

IFAD support the Kenyan government to reduce poverty through integration of producers and finance world. For all her labor as mother and housekeeper child care, transportation, errands cleaning, laundry, cooking, bill paying, grocery shopping her yearly salary would be over average salary of male full time work. (Newman 2002: 393) [18]

Despite significant shifts in attitudes towards gender roles and the accelerated entry of women into paid labor force in the past few decades, continuous to be predominantly female as they take the entire household and employment tasks. The research has a significant relationship with way the gender roles are in Kenya and the study area. Men have the traditional notion that the household duties are met for the women and failure leads to domestic violence, murder, assault, child abuse, divorce in the family.

The women in divorce in Emuhaya face total human rights violations and abuse.Bursary supported 151 Secondary School students went to the needy student, Kenya shillings 2,293,000 went to tertiary institutions for a total of 387 cases. The office of the Member of Parliament sponsored 31 Form one needy student who obtained 400 marks and above in Kenya certificate of primary Education (KCPE) at a cost of ksh 440,000. (Emuhaya News March 2010). The above show the support Emuhaya Constituency Development Fund (CDF) is putting in place on social support to improve the region, reduce poverty and the rate of criminal activities the youth may engage in. Emuhaya district Institution like Equity Bank and Kenya Commercial Bank have engaged the poor communities in small micro finance business through loaning credit systems. The bank support activities like education, sports, and poverty reduction activities in 2010. Equity Bank sponsored the best 2009 Kenya Secondary Certificate of Examination students 720,000 Kenya shillings to pursue University education in the Universities of their Choice.

There is need for improvement on infrastructures in the study area especially on roads, bridges, schools, water and sanitation, health, agriculture, electricity to enhance proper production to raise standards of living to reduce crime in the study area. 


\subsection{Findings of the relationship between level of education and crime}

It was hypothesized that there was no relationship between the level of education and tendency to commit crime among the Abanyole of Emuhaya District of Western Kenya.

The findings from testing the $\mathrm{H}_{1}$ reveal that there was a significant relationship between the levels of educational of the people and the tendency to commit crime in the region of study. Results support the work of Kulkarni (2005) showed that people who do not complete high school experience high poverty rates than those who completed high school and twice those who completed university. The study explains the impacts of education to individual income or standards of living. Education is key determinant of economic stability of a community.

The researcher feels that brain drain is an element of transfer of human resources from the needy area to develop others communities'. Its Emuhaya most people with good educational level, with good educational level, with good jobs have migrated from Bunyore compromising the leadership of the people. This was supported by a study carried out in Uganda by the Ministry of Finance Planning and Economic Development (Dec 2004) report on Poverty Eradication Action Plan (PEAP) showed that education in Uganda and Africa still has European influence and does not reflect the socio-economic, political, cultural needs and values at grass root levels. Employment of the educated is in big towns separating them from the aging parents in rural areas for greater pastures. The conflicts theorists view education in modern societies are serving to justify and maintain the status quo and further challengers the view that education is the main root course of social mobility and it can of set inequities in family backgrounds. According to the study area it could so because even the few who have gone to school, completed college have no employment so it beats the logic of income and standards of living if the spirit of inequality in education and resource is not addressed both locally and at National levels.[7]

Kornhblum (2003) show a conflict perspective on social research often ask questions whether schools are creating equal opportunities for the social and group advancement or whether they are working to justify inequality. Are they preparing students regardless of class, race, ethnicity or gender to rise to the social hierarchy (Kornblum 2003:555).[57]

This contradicts the studies carried out in Kenya in the 1990s on Universal free primary education where all were to get education up to Std 8 . The Secondary section was to be financed by the poor parents who have failed to meet the High School Education costs for most children. The standard 8 graduates cannot complete for any job apart from becoming house wives, prostitutes, bandits, gangsters in Kenya and the rural villagers where all sorts of criminal activities are witnessed.

Freymond (1996) support the study by agreeing that women are half the world's people and make up the most illiterate and poor, receive one tenth of the world's wages and own $1 \%$ of the world's property. This backs up the findings of the study that in Emuhaya women are the most vulnerable to poverty and can be attempted to commit crimes like divorce, separation, abandoning children (child abuse) practice commercial sex and the youths engage in property theft and gangster's formations, drugs abuse, and alcoholism. An explanation for findings from this study could be that low education attributes to criminal offenses in the study area due to lack of income and lack of the household needs.[29]

Herslin (2000) shows that education is one of the main approvals of reaching the goal to success which is hampered by the middle class who run the school systems. There the children of the poor are ill prepared for the bewildering world they confront with conflicts too sharp within their backgrounds. Their grammar shear words, ideas, punctuality, neatness, lack of paper and pencil skills all differ from those of middle class students. The schools that the most poor children attend are inferior to the school the educated children form high school classes. These barriers is an avenue of the school blocking them legitimate avenues of financial success and thus result to street children, robbery, burglary, selling drugs, pumping, prostitution, gambling and other income criminal activities. Some of the poor households find such illegal income producing crime to functional and the poor are drawn into them in appropriate numbers. Education has the strongest effects on economic status of the households. [30]

The people who have not completed high school experience higher poverty rates than those completed high school while those who go beyond high school, college or university earn more. Achievements of individual depend on the extent of the available opportunities. The research shows that parental involvement in educational process is a key element in motivating educational achievements especially through parents Teacher association (PTA) at school levels (Thompson and Hicky 2002).[12]

Thompson and Hicky (2002) warms in their research studies that the benefits of education are too high, yet the benefits of education may be invisible if the individual or person who achieved an education flew their home communities. These leads to brain drain leaving the society with no leadership and strategic planners and decision makers. The parents need to encourage the children to go school, avoid absenteeism, truancy and criminal activities like smoking tobacco, substance and drug abuse so that they learn to take up the leadership of the society in future.[12] 
The human rights legislation stress for equality right, guaranteed welfare right and economic rights that require the provision of education and protection against severe poverty and starvation. These laws apply to only those who have enough to subsidise for socio-economic needs like education and basic needs especially food which are hardily found among the marginalized poor in Kenya and Emuhaya the study region. There is a big contradiction between the equality rights that guarantees equal citizenship, equality before the law and nondiscrimination. There is segregation as the poor have to cope up with rural school while the middle class and the rich families attend urban model schools. Indeed most of them make it to university and take over their father's positions on retirement or death. An example is the Kenyan parliament which is full of sons and daughters of former parents in the government leadership including the political world. The rift between the poor and the rich Kenyans is high.

Bhorat and Leibbrant (2002) show the education has a paramount role on redeeming poverty, because it contributes to improve earnings of the poor both in job competition and earnings in a static labour market and a source of growth and employment. Thus the distribution of physical and human capital emerges from capital emerges from the theoretical and empirical literature as the key to the distribution. Consequences of growth inequality in education resulting from certain age cohorts who never attended education pass the same to their households from generation to generation.[65]

Education in technology has increased the educational and economics needs as the people can communicate, trade, study or access all they need through the internet, computers and phones. The world has been globalized. But the dangers of globalization are the promotion of white collar crimes among the systems, siphoning of public funds and budget misallocation leaving the poor more vulnerable to poverty. United Nations (1991) asserts that new technologies are used in confiscations of tribal land, frustration of land reformers or poisoning of labourers by chemical insecticides. These are crimes committed by educated people.

Schmalleger (2004) shows the effects of family divorce ruins the educational level of children and the socioeconomic status. The children of divorced parents live in depression leading to frustrations. Children in their undertakings become helpless and hopeless in school and dropping out of school. Divorce and separation creates avenues for child crimes like juvenile delinquency, rape, early marriage, stealing, gambling, child labour, murder, incest and even murder in households. [9]

Education improves the economic status of the community and the household. According to Owolabi (2006) employment of workers goes with skills and training and leads to higher productivity, making of critical decision that involves careful analysis of situations requires personal higher levels of education. As the saying goes nothing comes on a silver platter, Kenyans and the people of Emuhaya must challenge poverty situations through education to enhance agricultural production have improved innovative systems of investment to face the challenges of crime within a well streamlined legal. Owolabi (2006) emphasizes that educational qualifications early sought be to as a means to modern sector jobs and without leads to unemployment. [16]

Poorly educated societies have numerous criminal activities of chang'aa and busaa selling, drugs abuse and other serious violation of human rights while the educated take up sophisticated crimes of corruption, bribes as noted by the Kenya police, the judiciary taking bribes to change a case and delays of the due process to destroy as evidence. The workers violate the work codes and fraud government money ad services leading to poverty.

\subsection{Findings of the relationship between possession of property and crime}

It was hypothesized that there was no relationship on possession of property and the tendency of people to commit crime among the Abanyole of Emuhaya in Western Kenya.

Findings from the testing $\mathrm{H}_{1}$ revealed that there was significant relationship of the people's possession of poverty and tendency to commit crime. The result from this support the work of Bodice, Kane and Marcus (1999) which shows that the wealth of a society is determined ultimately by the productive capacity of its economy, goods and services that can be provided to its member. This production capacity is a function of real assets such as land, buildings, knowledge and machines that are used to produce goods and services and the skilled workers who are able to use the resources. Further research has established that financial assets contribute to the individual's wealth. Firm holding such as bonds, or stock deposits, life insurance, pension reserves corporate equity, mutual shares and debt securities are keys to investments and property reserves. [60]

However the results from these studies contradicted the work on the internet which http:/www/global/property.guide.com/Africa/Kenya/inheritance) sticks to the law of succession Act and civil procedure which applies to all cases interstate and testament succession in Kenya. The constitution guarantee foreigners of different Nationalities or religions to legally acquire, inherit, buy and sell property in Kenya both the movable and immovable. This scenario relates to a state that has no plight of its own people as far as human rights is concerned on the individual rights to life and property ownership. The Nation has opened up to foreigners and has failed to meet its obligation on investment plans and finance the rural communities to access 
property anywhere in Kenya. Currently there are clashes every where in Kenya on tribal lines and ethnicity, the political world is divided on whether to serve neither the citizens nor their personal agenda public property.

Thompson and Hicky (2002) showed that property crimes and non violent crimes are the most serious and include burglary (unlawful breaking with an intent to steal) larceny theft (theft of value exceeding US dollars 100) auto theft and arson (Internationally setting fire). This highly supports the last December 2007 election violence in Kenya where property and people were torched leading to death and enormous destruction of property. In addition criminal activities like embezzlement of property funds by public officials, receiving and selling stolen property, stealing money from banks and financial institutions, forgery, counterfeiting of money in Kenya in 2002 by YK-92 political leaders campaign during multiparty politics in Kenya. There is frequent stealing of livestock, household property from the poor families within the study area. [72]

An explanation for the findings from this study could be that low levels of property ownership could be contributing factor subjecting the people to steal others property. Crime could also be a contributor in hindering those who would like to invest and posse property in the region. There is burglary, larceny, stock theft, and embezzlement of project funds in most sectors of development in this study region, Arson cases were noted during 2007 presidential election when non-Luhyia properties were torched and stolen. Corruption and bribery is highly visible among the police and public servants in the region. Therefore there is need to improve on property ownership to generate resources to alleviate poverty in this region for peace and stability.

\section{Conclusion}

This study investigated the influence of poverty among the Abanyole of Emuhaya in Western Kenya. The study was intended to establish the relationship between financial standing, the employment, family structure, social support, the level of education and property ownership among the people and their tendency to commit crime in the study area. The purpose of the study was to generate ways of solving poverty issues in order to reduce crime amongst the youths and the vulnerable individuals in the community of Emuhaya District in Western Kenya. This was in relation to problem statement of the research that poverty has a great influence on crime due to unemployment, illiteracy, low levels of education, lack of property such as land, investments and he daily basic needs to stop hunger and starvation. There is social family support by CDF programmes, NGOs government on education, infrastructure, and health care, food relief but this is still like a drop in the ocean as people continue with criminal offences of selling illegal drugs and substances such as chang' aa and busaa (local beer), bhang, tobacco and other unreported illegal substances. There are frequent organized crimes in urban and rural settings such as burglary, robbery, murder of prominent people and watchmen, assaults, prostitution, rape, gambling, mugging, commercial sex, pick pocketing, gender based violence which take party in the study.

The study specifically sought to determine the factors that lead to the vicious cycle of poverty causes crime, develop plans to access and investigate criminal offences when committed in the region and they are solved by the law enforcers and policy makers in the study area. The study used the null hypothesis that there was no relationship between poverty and crime in the study area to establish the findings of the research on poverty and crime among the Abanyole people. The findings was that there was a significant relationship between the level of employment, education, financial standing, property ownership, social structure, social support and the tendency of people to commit crime in accordance to the analysis and interpretation of the results from 124, respondents in view of all these finding there is evident facts that there is poverty in Emuhaya district.

\section{Acknowledgement}

I acknowledge for God's providence, life and wisdom He has given for this study. Without this power and protection I could not have made it. My wife Jescah Wambani, the children Jackline, Kevin, Geoffrey were very supportive during study period. Special thanks goes to Education Office and my fellow staff members who were encouraging both materially and in knowledge during challenging times. I also take this opportunity to recognize the initiative and care of my parents Livingstone Ngutu and my mother Joyce Adori who funded my education and mentored me. To Mr Nelson Obwoge and Mr Kiboi Lecturers Kima International School of Theology (KIST), I thank them for preparing me for a visionary academic world. My final special regards goes to my supervisor Professor Samuel Salami for his guidance and encouragement towards the completion of my research. It is my humble desire to support the needy in the world.

\section{Reference}

[1]. Amarty, S. (1981) Poverty and Famine: An Essay on Entitlement and Deprivation. Walton Street: Oxford University Press.

[2]. Astin, A., Wangwe. S and Drabek, A.G. (1994) Economic Policy Experience in Africa. What have we learned? Nairobi, Africa Economic Research Consortium.

[3]. World Bank Report 1989: Sub Sahara Africa. 
[4]. Vihiga District Development Plan (2002 2008): Effective Management for sustainable Economic Growth and Development Reduction. Ministry of Finance: Republic of Kenya, Nairobi government printer.

[5]. Uganda Budget 2003 2004: What Relevance to Poverty Situation Review report No. 5 October 2003 Uganda Debt Network.

[6]. Uganda Poverty Eradication Action Plan (PEAP) 2004/5 - 2007/8: Ministry of Finance Planning and Economic Development December 2004.

[7]. Uganda Poverty Status Report (2005) Progress in Implementing the Poverty Eradication Action Plan. Kampala, Uganda.

[8]. UNDP(2006). Kenya National Development Report; Human Sanity and Human Development Deliberate Choice.

[9]. Schmallenger, F. (2004) Criminal Justic. A Brief Introduction ( $5^{\text {th }}$ Edition) New Jersey: Pearson Prentice Hall.

[10]. The Implementation of Fiscal and Tororo District, Review Report No. 7 Uganda Debt Network 2005 Kampala

[11]. The Short Oxford Dictionary (1993) United Kingdom London: Oxford University Press.

[12]. Thompson, W. and Hickey, J. V. (2002) Society in Focus. ( $4^{\text {th }}$ Edition) United States of America: Pearson Educational Company.

[13]. The Implementation of Fiscal and Tororo District, Review Report No. 7 Uganda Debt Network 2005 Kampala

[14]. Nyong'o, A (1990) Regional Integration in Africa. Unfinished Agenda: Nairobi :Academic Science Publishers.

[15]. Oso, W. Y. \& Owen, D. (2008) A General Guide to Writing Research Proposal and Report: Kampala: Makerere University Printery.

[16]. Owolabi, J. (2006): Quantitative methods of Educational Planning. Makerere University: Kampala Parkin, M. (20005) Micro economics ( $7^{\text {th }}$ Edition), New York: Pearson Addison Education.

[17]. Parillo, V. N. (2002) Contemporary Social Problems. $5^{\text {th }}$ Edition. United States: Allyn and Bacon

[18]. Newman, D. M. (2002) Sociology Exploring the Architecture of Everyday Life Untitled States. Sage Publication

[19]. Mulinge, D. M. (2008 ) A thesis on absenteeism and Academic Performance of Learners by HIV/AIDS in selected Primary schools in Muhala Zone Kibwezi District of Kenya of Maseno University. MA Thesis 2008

[20]. Html: file//bounce/ctttttt/Enabling the rural poor to overcome poverty in mht.

[21]. http:propertyleo.com/article.php?-id=15

[22]. http://bing/searchproperlyguide.com/Africa/Kenya/inheritance

[23]. Ian, R. (1977) Sociology. New York: Worth Publishers.

[24]. Inequality on poverty in Kenya http:/uk.oneworld.net/guides/Kenya/development

[25]. Kenya Pathfinder - Social Support and crime http:/www.pathfinder.org

[26]. Daily Nation (March 3, 2003). Kenyan shillings 12 million donated to fight hunger by Norway to purchase 265,000 bags of maize in West Pokot.

[27]. Daily Nation (March 3, 2003). Man kill two children after wife runs away page 5

[28]. Daily Nation (March 3, 2003). Officers hunt key suspects in fake money syndicate page 4.

[29]. Daily Nation (March 3, 2003). States sizes grabbed land.

[30]. Freymond, J. (1996). Overcoming Rural Poverty, Casin/Saa, Global 2000

[31]. Hersiln, j. M. (2000) Social Problems (5 $5^{\text {th }}$ Edition) New Jersey: Upper Saddle River

[32]. Effects of poverty on society http://www.answer.com/topic/poverty

[33]. Eshleman, J. Barbara, R., Cashion, G. Laurence, A. B. (2003). An Introduction to Sociology. United States: Horizon Publishers.

[34]. Kin, H. H. (1999) Guns and Violence. United States: Green Haven press

[35]. Kenyan Constitution 2010

[36]. Kenya National Examination Council 2010- Emuhaya district results

[37]. Kenya National Survey 2009

[38]. Ndeye, S. (2005) International alerts Gender and conflict Transformation in Great Lakes Region of Africa

[39]. Kinyua, B. (2006).Evaluation of the Relevancy and Efficacy of the Constituency Development Fund. A case Study of Rural Igembe Meru, North District Kenya, Maseno University. MA Thesis 2006

[40]. Budget Transparency in Uganda Discussion Paper No. 6 of January.Uganda Debt Network. Kampala.

[41]. Colander, D. C. (2004) Economics ( $5^{\text {th }}$ Edition). New York: McGraw Hill.

[42]. Kenya National Poll survey- April 2009

[43]. Kenya Constituency Development fund act 2003

[44]. Uganda Implementation of fiscal decentralization strategy report No 7 Debt network 2005

[45]. Emuhaya Constituency News IssueNo5 Jan - March 2010

[46]. The Implementation of Fiscal and Tororo District, Review Report No. 7 Uganda Debt Network 2005 Kampala.

[47]. Property and Crime in Kenya- http:/globaproperty.Guide.com/ Africa/ Kenya/ inheritance.

[48]. Ray, D. \& Kiser, C. (1993) Drugs, Society and Human Behaviour (6 ${ }^{\text {th }}$ Edition). St Louis Missouri: Mosby.

[49]. Report No.11650-KE (Sept 30, 1993).Kenya Employment Growth and Poverty Alleviation.

[50]. Republic of Kenya (March, 12 2004). Investment Programme for the Economic Recovery Strategy for Wealth and Employment creation. $2003-2007$

[51]. Sen., A. (1987). Poverty and Famine: An essay on Entitlement and Deprivation. London: Oxford University Press.

[52]. Vihiga District Development Plan (2002 2008): Effective Management for sustainable Economic Growth and Development Reduction. Ministry of Finance: Republic of Kenya, Nairobi government printer.

[53]. Watkins, K. (1995): Oxfam Poverty United Kingdom/Ireland Oxfam publications.

[54]. Wright, R. S., \& Wright, D. G. (1993). Creating and maintaining the drug - Free Workforce. New York: McGraw Hill.

[55]. Nyatwanga, A. H. (2007) Poverty on Academic Performance in Nyamira Divison, Nyamira District Kenya. SPGS Maseno University. MA Thesis 2007

[56]. Kornhbum, W. (2003) Sociology in the Changing World. United States: Thomson Wada worth.

[57]. Kurland, L. M. D (1990). Coping with Family Violence. New York: Rosen Publication Group.

[58]. [59] Laver, R. H., \& Laver, J. C. (2002). Social Problems and the Quality of Life. New York: McGraw. Hill Higher Education.

[59]. Marcus, B. K. (1999). Investment ( $4^{\text {th }}$ Edition) New York: Mc Hill.

[60]. Marsden, D. (1989). Theory of Employment Systems. Micro - Foundation of Societal Diversity. United Kingdom: Oxford University press.

[61]. Mauri, (2004) Saving s and Development. Italy: Milan.

[62]. Mugenda, O. M. \& Mugenda, A.G. (2003). Research Methods: Quantitative and Qualitative Approaches. Nairobi: Nairobi acts Press

[63]. Horton, P. B. \& Leslie, G. R. The Sociology of Social Problems ( $6^{\text {th }}$ Edition). Englewood Cliff, New Jersey: Prentice Hall.

[64]. Bhorrat, H. Leibbrant, M., Maziya. M., Berg, S.V.D. \& Woodland, I. (2001). Fighting Poverty. Labour Markets and Inequality in South Africa. Cape Town: VCT Press. 
[65]. Bohm, R. M. and Keith, N. H. (1999) Introduction to criminal Justice ( $2^{\text {nd }}$ Edition) United States Genco/McGraw Hill.

[66]. Bhreth, S. A. (1997). Overcoming Rural Poverty in Africa. Geneva: Centre Rural Applied Geneva: Centre for Applied Studies in International negotiations.

[67]. Brown, L. (1993). The New shorter Oxford English Dictionary on Historical principles: Volume 2, N - Z, New York: Oxford University Press.

[68]. David, D, Bannet, \& Laura P. H. (2004) New York: McGraw Hill/Irwin.

[69]. Amin, M. E (2005). Social Science Research. Conception, Methodology and Analysis. Kampala: Makerere University Printery.

[70]. Amiti, E, W. (1998). Educational Psychology. United States: Allyn and Bacon.

[71]. Thomson, W. \& Hickey J. V (2002) Society in Focus ( $4^{\text {th }}$ Edition), Boston Massachusetts: Pearson Education Company.

[72]. Farrgains, J. (1993). Research Methods for Social Work. Pacific Grove. California: Book/Cole. 